\title{
Thermodynamic analysis of DNA binding by a Bacillus single stranded DNA binding protein
}

\author{
Esther E Biswas-Fiss ${ }^{1,2}$, Jirayu Kukiratirat ${ }^{1}$ and Subhasis B Biswas ${ }^{1 *}$
}

\begin{abstract}
Background: Single-stranded DNA binding proteins (SSB) are essential for DNA replication, repair, and recombination in all organisms. SSB works in concert with a variety of DNA metabolizing enzymes such as DNA polymerase.

Results: We have cloned and purified SSB from Bacillus anthracis (SSB $B_{B A}$ ). In the absence of DNA, at concentrations $\leq 100 \mu \mathrm{g} / \mathrm{ml}$, SSB $B_{B A}$ did not form a stable tetramer and appeared to resemble bacteriophage T4 gene 32 protein. Fluorescence anisotropy studies demonstrated that $\mathrm{SSB}_{\mathrm{BA}}$ bound SSDNA with high affinity comparable to other prokaryotic SSBs. Thermodynamic analysis indicated both hydrophobic and ionic contributions to ssDNA binding. FRET analysis of oligo(dT) 70 binding suggested that $\mathrm{SSB}_{\mathrm{BA}}$ forms a tetrameric assembly upon SsDNA binding. This report provides evidence of a bacterial SSB that utilizes a novel mechanism for DNA binding through the formation of a transient tetrameric structure.
\end{abstract}

Conclusions: Unlike other prokaryotic SSB proteins, $S_{S B}$ BA from Bacillus anthracis appeared to be monomeric at concentrations $\leq 100 \mu \mathrm{g} / \mathrm{ml}$ as determined by SE-HPLC. SSB $B_{B A}$ retained its ability to bind ssDNA with very high affinity, comparable to SSB proteins which are tetrameric. In the presence of a long SSDNA template, SSB $B_{B A}$ appears to form a transient tetrameric structure. Its unique structure appears to be due to the cumulative effect of multiple key amino acid changes in its sequence during evolution, leading to perturbation of stable dimer and tetramer formation. The structural features of $\mathrm{SSB}_{\mathrm{BA}}$ could promote facile assembly and disassembly of the protein-DNA complex required in processes such as DNA replication.

Keywords: Single-stranded DNA binding protein (SSB), DNA replication, Fluorescence anisotropy, ssDNA binding, Protein-DNA complex

\section{Background}

Nearly all cellular nucleic acid transactions, including DNA replication, repair and recombination require the activity of a single stranded DNA binding protein (SSB) [1-7]. SSB proteins and are found throughout nature and their functional importance is underscored by their presence in prokaryotes, archaea, and eukaryotes including mammals [1]. Among its multifaceted roles, upon binding to ssDNA, SSB prevents the reformation of duplex DNA making it possible for other enzymes such as DNA polymerase to use ssDNA as substrate. In addition, the binding of SSB-type proteins protects the ssDNA

\footnotetext{
* Correspondence: biswassb@umdnj.edu

'Department of Molecular Biology, School of Osteopathic Medicine \& Graduate School of Biomedical Sciences, University of Medicine \& Dentistry of New Jersey, Stratford, NJ 08084, USA

Full list of author information is available at the end of the article
}

molecules from attack by intracellular nucleases. Although not possessing intrinsic enzymatic activity in and of themselves, SSB proteins are known to influence the activities of many enzymes as well as to organize the multi-protein complexes required for processes such as DNA replication, recombination and DNA repair [8-11].

The function of SSB during DNA replication has been extensively studied in E. coli, which serves as the prototypical model system for prokaryotes and eukaryotes alike. In $E$. coli, the large nucleoprotein replication initiation complex is stabilized by single stranded DNA binding protein, following which DNA is unwound by the DnaB helicase protein. Efficient DNA unwinding activity of DnaB protein in progression of the replication fork in E. coli is strongly dependent on the continued action of a cognate SSB $[12,13]$. SSB works in concert with DnaB helicase, DNA primase, and DNA polymerase III holoenzyme

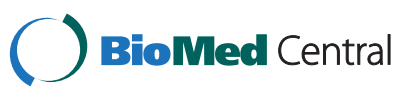


during E. coli DNA replication $[5,9,12,14,15]$. Phage $\lambda$ DNA replication requires the participation of host $E$. coli SSB as well $[16,17]$. In archaea and eukaryotes, its functional homolog, Replication Protein A (RPA), carries out the role of organizing and stabilizing the replisome during DNA replication $[1,3,10,18-21]$.

Vital to its function in DNA metabolism is the structure of SSB. In the Gram-negative bacteria, SSB is homotetrameric, with each monomer contributing a single ssDNA-binding domain to the functional form. The eukaryotic RPA is composed of three subunits (RPA70, RPA32, and RPA14) and functions as a heterotrimer through the use of four ssDNA-binding domains $[2,3,18]$.

Unlike E. coli SSB, single stranded DNA binding protein from bacteriophage $\mathrm{T} 4$, the gene 32 protein, is a monomer. T4 gene 32 protein can form multimers at high concentration induced by high salt and high $\mathrm{pH}$ [22]. Kim and Richardson demonstrated that the bacteriophage T7 SSB, the gene 2.5 protein, is a dimer [23]. The T7 gene 2.5 SSB appears to bind DNA as a dimer. The ssDNA binding affinities of both T4 and T7 SSBs are lower than that observed with $E$. coli SSB. Despite these differences, ssDNA binding of SSB proteins using $\mathrm{OB}$ fold-domains (oligosaccharide/oligonucleotide binding domains) appears to be universal throughout all systems described to date [1].

The E. coli SSB is highly cooperative in ssDNA binding that is influenced by salt concentration [24,25]. Recent studies indicate that SSB has at least two distinct modes of ssDNA binding [26]. The binding is modulated by monovalent salts. At very low salt concentration $(<10 \mathrm{mM} \mathrm{NaCl}), \mathrm{SSB}$ binds ssDNA using two of its four subunits in a highly cooperative manner and occludes only 35 nucleotides $\left[(\mathrm{SSB})_{35}\right.$ mode]. On the other hand, at higher salt concentrations $(>200 \mathrm{mM} \mathrm{NaCl})$, it binds to ssDNA using all four subunits and protects $\sim 65$ nucleotides $\left[(\mathrm{SSB})_{65}\right.$ mode]. It is not clear how the ssDNA binding is altered between 10 and $200 \mathrm{mM} \mathrm{NaCl}$. Higher-order forms of SSB in ssDNA bound states, based on high resolution electron microscopic studies of SSB-ssDNA complex, have also been reported [27]. Chrysogelos and Griffith discovered that repeated freezing-thawing of $E$. coli SSB leads to the formation of unique strings of tetramers [28].

Gram-positive bacterial protein sequences do not form a monophyletic group, but are intermixed with plasmid and phage sequences [29,30]. Gene organization in these organisms can differ from that observed in Gramnegative $E$. coli and these organisms may contain multiple paralogues [31,32]. Sequence analysis indicated that Gram-positive SSBs have a highly conserved nearlyidentical (>90\% identity) N-terminal ssDNA binding as well as monomer-monomer interaction domains but they differ to some extent from the Gram-negative SSBs.
We have investigated the structure and ssDNA binding of a Gram-positive bacillus $\mathrm{SSB}\left(\mathrm{SSB}_{\mathrm{BA}}\right)$ in order to understand its mechanism of action of SSBs in these organisms. We present here a report of a Gram-positive SSB that utilizes a novel structural mechanism for protein-DNA interaction using a transient tetramer formation.

\section{Results}

The single-stranded DNA binding protein ORF of B. anthracis (BAS5326) was identified by BLAST search of the annotated sequenced genome of $B$. anthracis Stern strain [33,34]. The ORF encodes a polypeptide of 172 amino acid residues with a predicted molecular weight of $19.2 \mathrm{kDa}$.

\section{Sequence analysis of $\mathrm{SSB}_{\mathrm{BA}}$}

The amino acid sequence of the N-terminal ssDNA binding and protein-protein interaction domains responsible for dimer and tetramer formation of $\mathrm{SSB}_{\mathrm{BA}}$ were compared with the sequences of a Gram-positive (Bacillus anthracis) and Gram-negative (E. coli and Salmonella typhimurium) SSB proteins. Multiple-alignment of these sequences, using ClustalW2, is shown in Figure 1. In general, a high degree of sequence homology among SSBs was observed only in the N-terminal two-thirds of the proteins. In the N-terminus two-third, sequence homology (identity + similarity) of $\mathrm{SSB}_{\mathrm{BA}}$ was observed with Gram-positive SSBs and was estimated to be $\sim 54 \%$, whereas, it was $\geq 90 \%$ among Gram-negative SSBs. Amino acid residues 1-46 constitute the major portion of the SSB core domain and contain the OB DNA binding fold. The second region of homology observed was between residues 51-104 (Figure 1). A third area of homology was also observed in the last six residues with the sequence, DDDLPF, which corresponds to the acidic carboxy-terminal domain characteristic of eubacteria; this sequence is required for interaction with recombination, replication and repair machineries $[35,36]$. The $\mathrm{C}$ terminal region lacked significant homology even among Gram-negative SSBs in the region between the residues 100-166 among these SSBs [37].

\section{Purification of $\mathrm{SSB}_{\mathrm{BA}}$}

Recombinant $\mathrm{SSB}_{\mathrm{BA}}$ was highly soluble when expressed in $E$. coli. It was purified using a combination of ammonium sulfate fractionation as well as conventional ion exchange chromatography. These steps resulted in homogenous $\mathrm{SSB}_{\mathrm{BA}}$ (Figure 2A). In SE-HPLC analysis of purified $\mathrm{SSB}_{\mathrm{BA}}(100 \mu \mathrm{g} / \mathrm{ml})$ the protein eluted as a single peak with an elution volume consistent with that of a monomer (Figure 3).

To test the biological activity of $\mathrm{SSB}_{\mathrm{BA}}$ we measured its ability to stimulate its cognate $\mathrm{DnaB}, \mathrm{DnaB}_{\mathrm{BA}}$, using a FRET based DNA helicase assay. It was based on the 


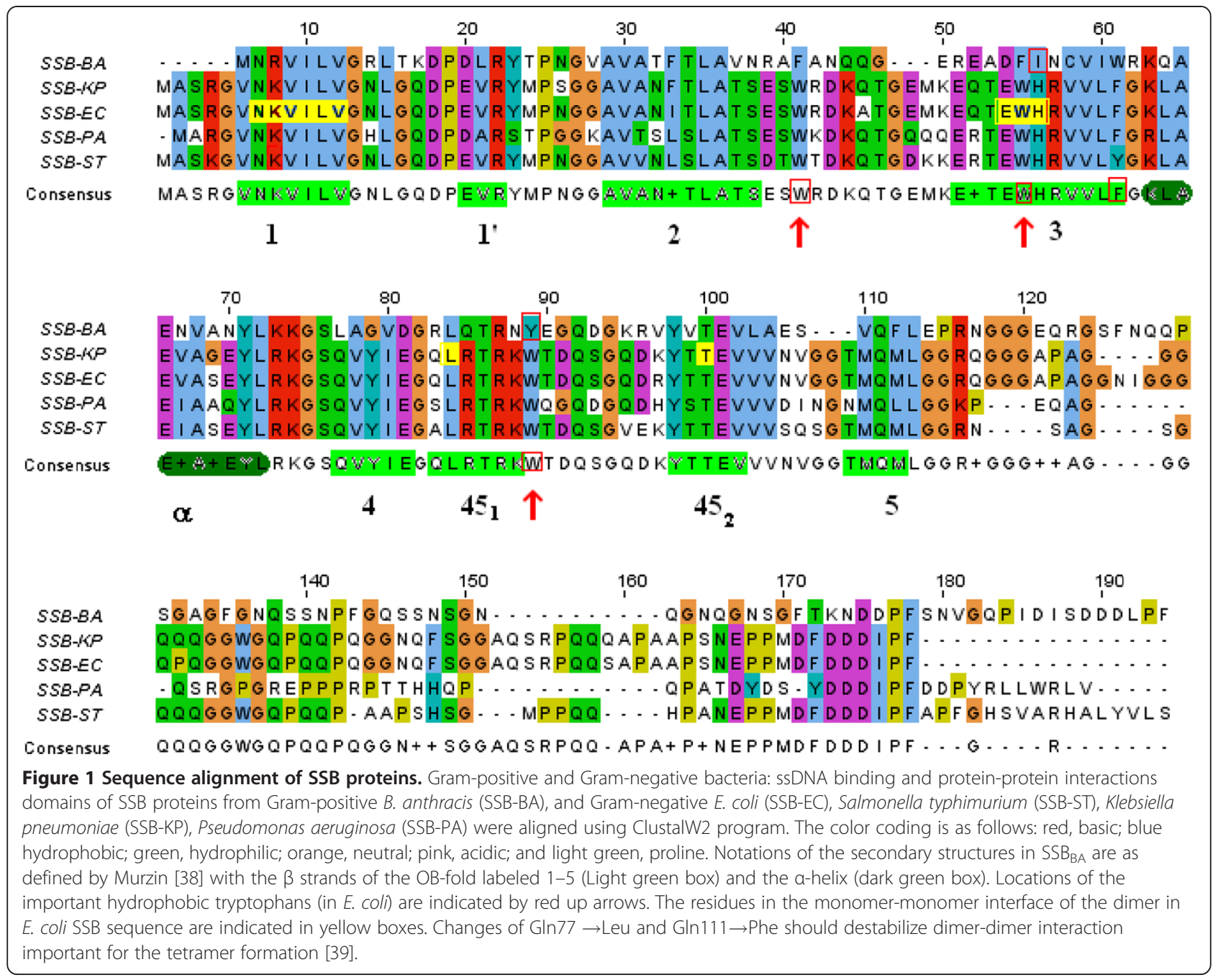

ability of $\mathrm{SSB}_{\mathrm{BA}}$ to stimulate DNA unwinding activity of its cognate DNA helicase, $D_{n a B}$ (Figure 2). In the absence of $\mathrm{SSB}_{\mathrm{BA}}$, DNA unwinding by $\mathrm{DnaB}_{\mathrm{BA}}$ was limited (Figure $2 \mathrm{~B}$ ) and was greatly stimulated in the presence of $\mathrm{SSB}_{\mathrm{BA}}$ (Figure 2C). The stimulation of the DNA helicase activity of $\mathrm{DnaB}_{\mathrm{BA}}$ in the presence of the purified $\mathrm{SSB}_{\mathrm{BA}}$ was $>10$ fold which was as expected for the cognate SSB [13].

\section{Mechanism of ssDNA binding by $\mathrm{SSB}_{\mathrm{BA}}$}

Fluorescence anisotropy-based titration of a DNAfluorophore by the DNA binding protein is a direct methodology for determining affinity of protein-DNA complexes. Following this approach, 5'-Fluorescein-labeled oligo $(\mathrm{dT})_{20}\left(\mathrm{Fl}(\mathrm{dT})_{20}\right)$ was used as a fluorescence anisotropy probe for analyzing $\mathrm{SSB}_{\mathrm{BA}}$ and ssDNA interactions. In order to determine the binding constant for $\mathrm{SSB}_{\mathrm{BA}}$, the interaction of $\mathrm{SSB}_{\mathrm{BA}}$ with $5^{\prime}$-flourescein labeled oligo $(\mathrm{dT})_{20}$ was examined at $25^{\circ} \mathrm{C}$ and in buffer $\mathrm{B}$ containing $0.1 \mathrm{nM} \mathrm{Fl}-(\mathrm{dT})_{20}, 25 \mathrm{mM} \mathrm{KCl}$ and $5 \mathrm{mM} \mathrm{Mg}^{+2}$. Fl- $(\mathrm{dT})_{20}$ was titrated with $\mathrm{SSB}_{\mathrm{BA}}$ until saturation in anisotropy was observed. The anisotropy values at various $\mathrm{SSB}_{\mathrm{BA}}$ concentrations were used to create a binding isotherm as a semi$\log$ plot as shown in Figure 4. At very low $\mathrm{SSB}_{\mathrm{BA}}$ concentrations, very small anisotropy changes and a flat plateau $(\sim 43 \mathrm{~mA})$ were observed that were attributed to Fl- $(\mathrm{dT})_{20}$. Upon further addition of $\mathrm{SSB}_{\mathrm{BA}}$, the anisotropy value increased with an increase in $\mathrm{SSB}_{\mathrm{BA}} \cdot \mathrm{Fl}-(\mathrm{dT})_{20}$ complex formation. A sigmoid binding isotherm with saturation binding at high $\mathrm{SSB}_{\mathrm{BA}}$ concentration was observed with maximum anisotropy of $184 \pm 5 \mathrm{~mA}$. At higher SSB concentration $(\geq 1 \mu \mathrm{M})$, anisotropy did not change significantly (data not shown). Nonlinear regression analysis, using a sigmoidal dose-response equation, of the data allowed for determination of the $\mathrm{SSB}_{\mathrm{BA}}$ concentration at which $50 \%$ of the ligand was in bound form $\left(\mathrm{EC}_{50}\right)$; that value corresponds to the apparent dissociation constant. The $\mathrm{K}_{\mathrm{D}}$ for $\mathrm{SSB}_{\mathrm{BA}} \cdot \mathrm{Fl}-(\mathrm{dT})_{20}$ complex was $1.0 \pm 0.1 \times 10^{-9} \mathrm{M}$. The Hill coefficient was $1.6 \pm 0.6$ indicating a possible binding of one to two molecules of $\mathrm{SSB}_{\mathrm{BA}}$ to $\mathrm{Fl}-(\mathrm{dT})_{20}$, which is 


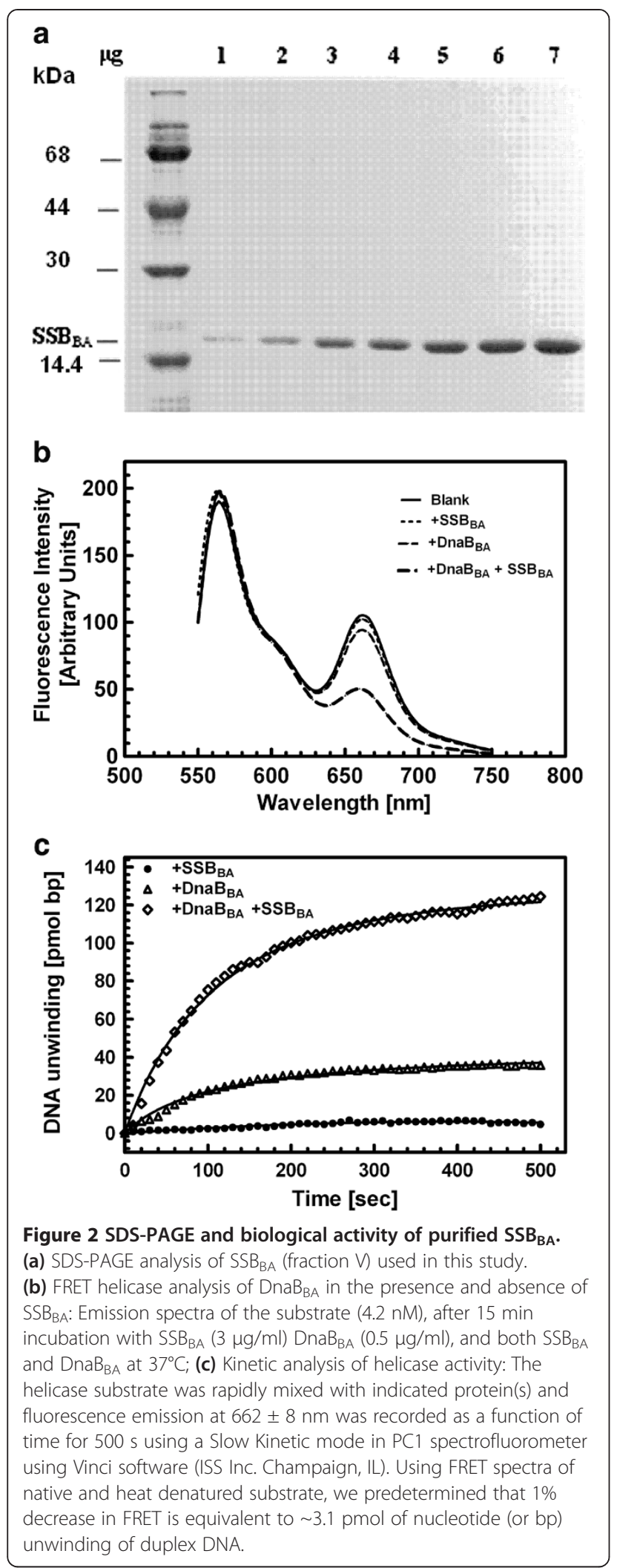

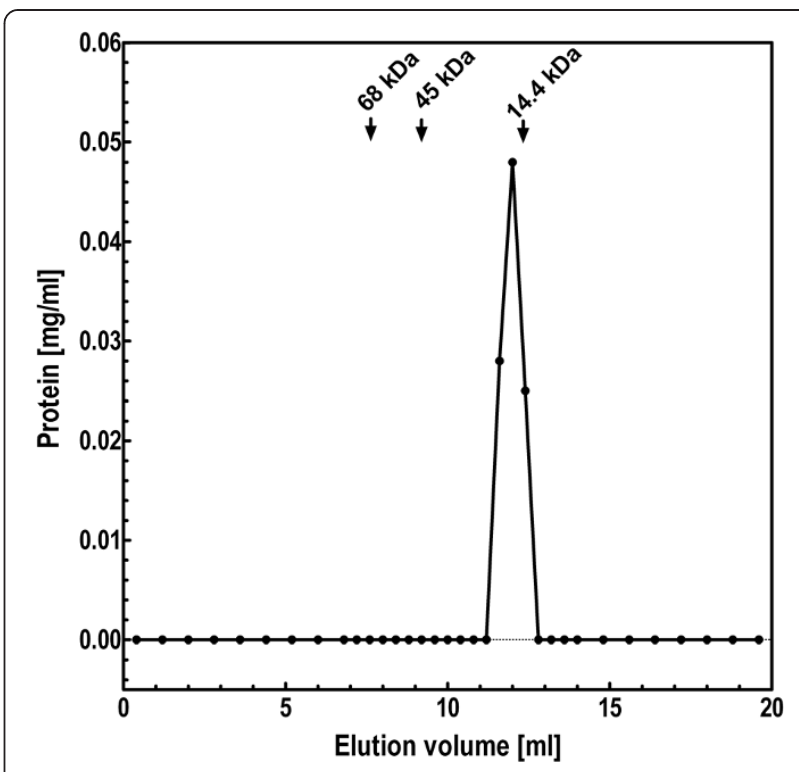

Figure 3 Size exclusion HPLC analysis of $\mathrm{SSB}_{\mathrm{BA}}$.Size exclusion HPLC analysis of $S_{S B} B_{B A}$. The native molecular mass of $S_{S B} B_{B A}$ Fraction $\vee$ was investigated using a TSK GS3000SW gel filtration column using A-100 as running buffer. Twenty micrograms of SSB $B_{B A}$ was injected and the column was eluted at $0.4 \mathrm{ml} / \mathrm{min}$. and $0.4 \mathrm{ml}$ fractions were collected. The gel filtration standards were BSA $(68 \mathrm{kDa})$ and ovalbumin $(44 \mathrm{kDa})$ and lysozyme $(15 \mathrm{kDa})$.

not surprising considering the fact that $\mathrm{SSB}_{\mathrm{BA}}$ does not form a stable tetramer. A simple hyperbolic fit of the anisotropy data was also carried out (Figure 4 inset). The estimated $K_{D}$ value was $1.2 \pm 0.8 \times 10^{-9} \mathrm{M}$. In order to determine the correct method of analysis of binding data, we have examined the "Goodness of Fit" using both models. The $\mathrm{R}^{2}$ value for the sigmoidal dose-response model was found to be 0.98 , whereas, for the simple hyperbolic model was 0.94 . The Ftest using the values of degrees-of-freedom and absolute sum of squares, gave an F-value of 22.4 which correlated well with the $R^{2}$ values and clearly demonstrated that the sigmoidal dose-response model as the correct model/equation for fitting anisotropy binding data for such analysis.

\section{Thermodynamics of ssDNA binding}

In order to understand the thermodynamics of $\mathrm{SSB}_{\mathrm{BA} \cdot \mathrm{SS} D N A}$ binding interactions, we have analyzed $\mathrm{SSB}_{\mathrm{BA}}$ binding to ssDNA at different temperatures over a range of $20-37^{\circ} \mathrm{C}$. The temperature-dependent binding isotherms for $\mathrm{SSB}_{\mathrm{BA}}$ and $\mathrm{Fl}-(\mathrm{dT})_{20}$ are presented in Figure 5A. Higher anisotropy values observed at 20 or $25^{\circ} \mathrm{C}$ were due to glycerol used in this assay. As the temperature increased, an overall decrease in anisotropy value was observed for both the free and bound oligonucleotides. This overall decrease in anisotropy value is attributed to the decrease in viscosity of the solution with increasing temperature which was somewhat attenuated by adding glycerol. With a decrease in 


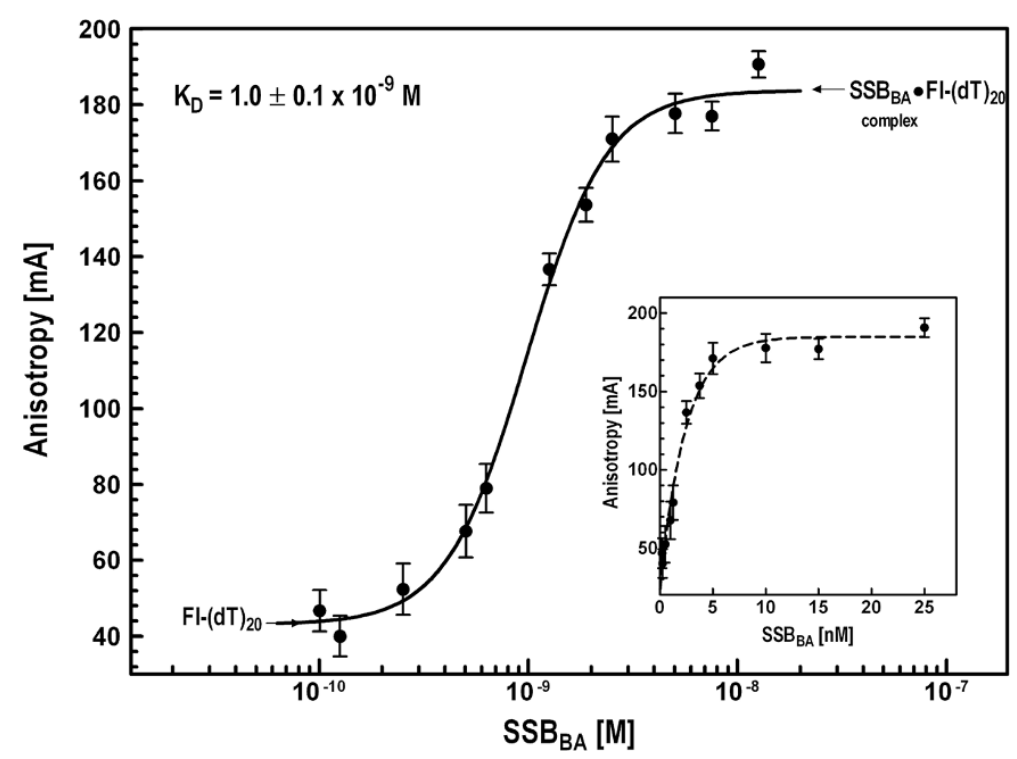

Figure 4 Fluorescence anisotropy analysis of equilibrium ssDNA binding by SSB $_{B A}$. SSDNA binding was measured using fluorescence anisotropy of $\mathrm{Fl}-(\mathrm{dT})_{20}$ oligonucleotide probe using the fluorescence of its $5^{\prime}$-fluorescein moiety using $480 \mathrm{~nm}$ excitation and $540 \mathrm{~nm}$ emission of fluorescein as described in Materials \& Methods. Titration was carried out with $\mathrm{SSB}_{\mathrm{BA}}$ and fluorescence anisotropy of Fl-(dT) 20 was measured. As indicated, anisotropy of free $\mathrm{Fl}-(\mathrm{dT})_{20}$ oligonucleotide probe was $44 \pm 5 \mathrm{~mA}$ and that of the $\mathrm{SSB}_{\mathrm{BA}} \cdot \mathrm{Fl}-(\mathrm{dT})_{20}$ complex was $182 \pm 6 \mathrm{~mA}$. Anisotropy values were plotted against log of $\mathrm{SSB}_{\mathrm{BA}}$ concentration and the plots were analyzed by nonlinear regression using Prism 6.0. The error bars indicate standard deviation. [Inset] A simple plot of the data fitted to single association hyperbolic function.

temperature, the viscosity as well as the anisotropy values appeared to increase [40]. Analysis of the binding curve data for $K_{D}$ showed the dissociation constants increased steadily from $20^{\circ} \mathrm{C}$ to $37^{\circ} \mathrm{C}$. We did not observe any significant change in the Hill coefficient with temperature. This increase in $\mathrm{K}_{\mathrm{D}}$ could likely be due to the dissociation of the protein.DNA complex at higher temperatures. The $\mathrm{DnaA}_{\mathrm{BA}}$. DNA complex was most stable at $20-25^{\circ} \mathrm{C}$.

The dissociation constants obtained at varying temperatures were used to evaluate the thermodynamic properties of DNA binding. We have plotted the dissociation constants using the Van't Hoff equation, $\ln K_{D}=-\Delta H^{\circ} / R T$, where $\Delta \mathrm{H}^{\circ}$ is the enthalpy change and $\mathrm{T}$ and $\mathrm{R}$ are the temperature and gas constant respectively, with the dissociation constants derived from $20,25,30$, and $37^{\circ} \mathrm{C}$ (Figure 5B). The plot is linear for temperatures $20^{\circ} \mathrm{C}$ to $37^{\circ} \mathrm{C}$ and it diverges from linearity below $20^{\circ} \mathrm{C}$. The slope of the Van't Hoff plot was used to derive the change in enthalpy $\left(\Delta \mathrm{H}^{\circ}\right)$ at $25^{\circ} \mathrm{C}\left(33.9 \mathrm{~kJ} \mathrm{~mol}^{-1}\right)$. The change in entropy $\left(\Delta S^{\circ}\right)$ was calculated to be $56.9 \mathrm{~J} \mathrm{~mol}^{-1} \mathrm{~K}^{-1}$. Thus, it appears that the formation of the $\mathrm{SSB}_{\mathrm{BA}} \cdot \mathrm{sSDNA}$ complex has a strong entropic or hydrophobic component to the overall protein-DNA interaction.

In addition to hydrophobic interaction between $\mathrm{SSB}_{\mathrm{BA}}$ and ssDNA, we analyzed the contribution of ionic interactions, if any, in the complex formation. Fluorescence anisotropy was used determine the $K_{D}$ of formation of $\mathrm{SSB}_{\mathrm{BA}} \cdot \mathrm{SSDNA}$ complex as a function of $\mathrm{NaCl}$ concentration. The binding isotherm at different salt concentrations was generated using $\mathrm{SSB}_{\mathrm{BA}}$ titration of ssDNA at $25^{\circ} \mathrm{C}$ (Figure 6A). Each titration curve fits according to a single site binding isotherm. The data shows that highest affinity binding occurs at $0-25 \mathrm{mM} \mathrm{NaCl}$. The dissociation constant increased steadily from $0-250 \mathrm{mM} \mathrm{NaCl}$. The most striking change was in the values of the Hill coefficient. At $0 \mathrm{mM} \mathrm{NaCl}$, it was $1.9 \pm 0.6$ and steadily decreased to $0.9 \pm$ 0.1 at $150 \mathrm{mM} \mathrm{NaCl}$ and beyond. It could indicate that at $0 \mathrm{mM} \mathrm{NaCl}, \mathrm{SSB}_{\mathrm{BA}}$ was forming a predominantly dimeric structure which transformed into monomeric at higher $\mathrm{NaCl}$ concentration. However, at very low ionic strength, non-specific protein-protein interactions could not be ruled out. A thermodynamic linkage plot for ssDNA binding as a function of $\mathrm{NaCl}$ (Figure 6B) was generated from the $\mathrm{K}_{\mathrm{D}}$ values obtained from Figure 6A. The presence of a negative slope was indicative of a net ion release [41]. The data were analyzed using the following equation to determine the number of ions released upon binding:

$$
\Delta \mathrm{n}_{\text {ions }}=\ln \left(1 / \mathrm{K}_{\mathrm{D}}\right) / \ln [\mathrm{NaCl}]
$$

The analysis suggests that upon $\mathrm{SSB}_{\mathrm{BA}} \cdot \mathrm{ssDNA}$ complex formation, only one ion was released from the 


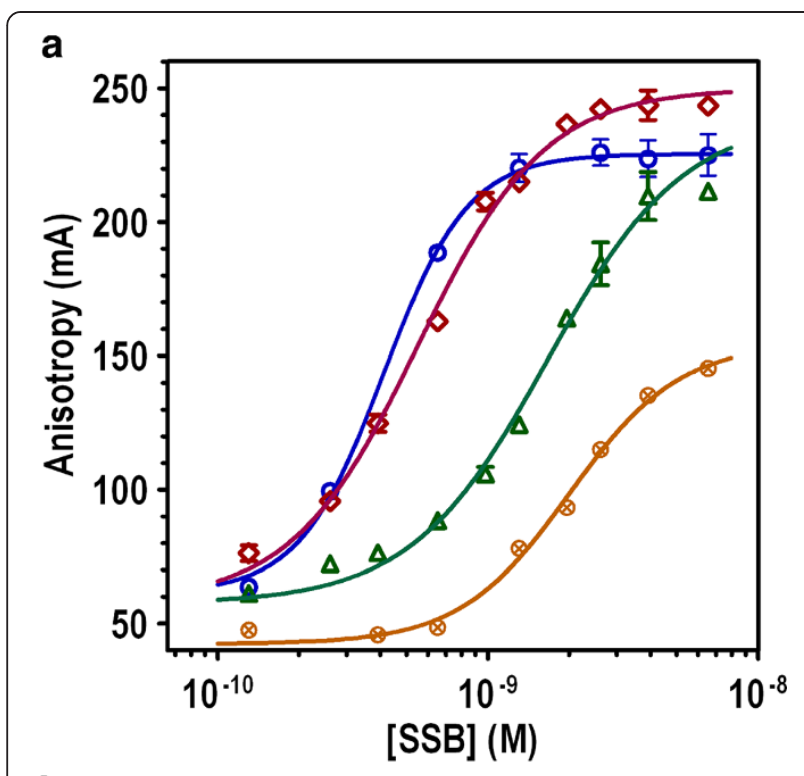

b

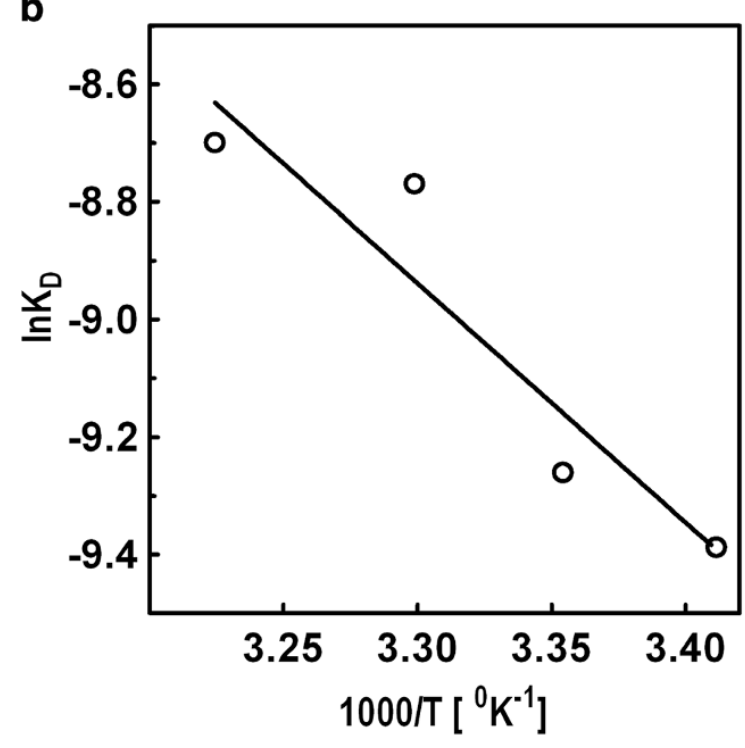

Figure 5 Temperature dependence of $\mathrm{SSB}_{\mathrm{BA}} \cdot \mathrm{ssDNA}$ complex formation. Temperature dependence of $S S D N A$ binding by $S_{S B} B_{B A}$ was measured at temperatures as indicated. (a) Binding isotherms for $S_{S B_{B A}}$ binding to $S S D N A$ at seven temperatures: $20^{\circ} \mathrm{C}, 25^{\circ} \mathrm{C}, 32^{\circ} \mathrm{C}$ and $37^{\circ} \mathrm{C}$ are shown. The concentration of the oligonucleotide was $1.0 \mathrm{nM}$ and $25 \mathrm{mM} \mathrm{NaCl}$ was added. (b) Van't Hoff plot was made using the analysis of the $K_{D}$ values obtained from the nonlinear regression of plot in $5 \mathrm{~A}$.

protein-DNA interface. These results appeared to indicate a small but significant contribution of ionic interaction in the ssDNA binding.

\section{Structural analysis of $\mathrm{SSB}_{\mathrm{BA}}$ by homology modeling}

The $\mathrm{SSB}_{\mathrm{BA}}$ sequence was further analyzed for secondary structure using Rosetta software (http://robetta.org/fragmentsubmit.jsp). Rosetta analysis indicated that there

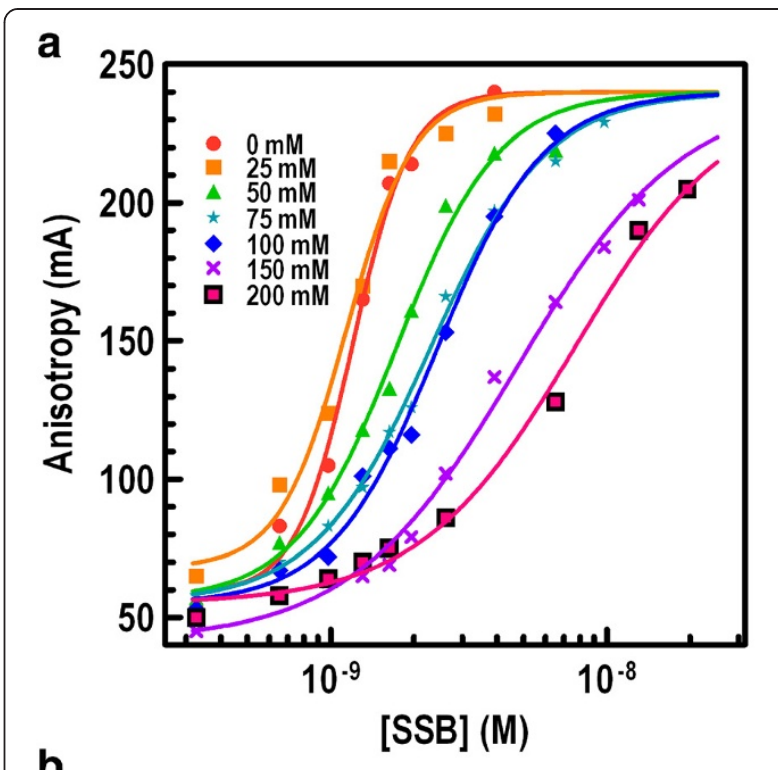

b

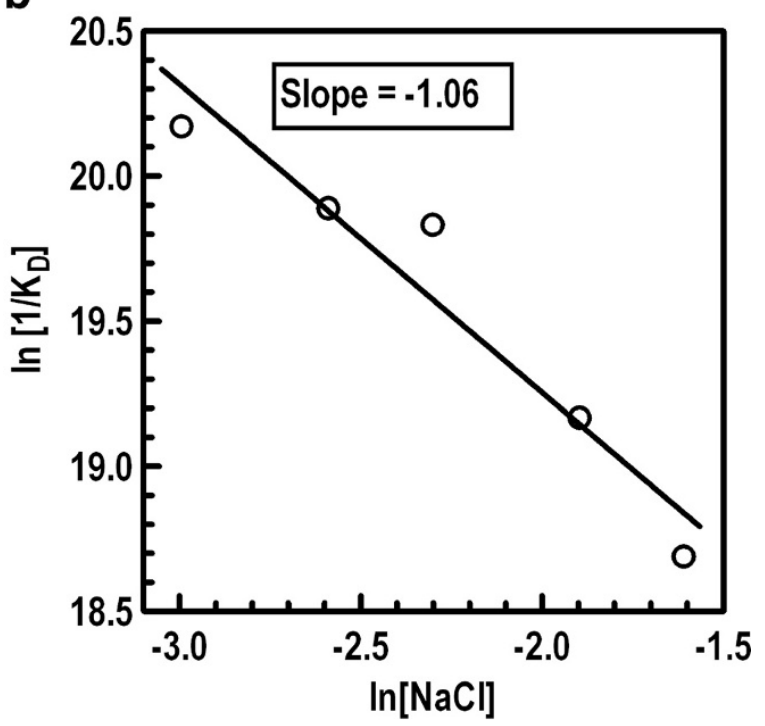

Figure 6 lonic strength dependence of $\mathrm{SSB}_{\mathrm{BA}} \cdot \mathrm{SSDNA}$ complex formation. lonic strength dependence of SSDNA binding by SSBBA was measured at $\mathrm{NaCl}$ concentration as indicated. (a) Binding isotherms for $\mathrm{SSB}_{\mathrm{BA}}$ binding to ssDNA at six $\mathrm{NaCl}$ concentrations: 0 , 25, 50, 100, 150, and $200 \mathrm{mM}$. (b) Thermodynamic linkage plot for $\mathrm{SSB}_{\mathrm{BA}}$ binding to SSDNA as a function of $\mathrm{NaCl}$ concentration. The net average number of ions released upon complex formation was derived from the slope of the plot.

are at least five significant $\beta$ strand structures and a single $\alpha$-helix in the N-terminal half of the molecule (data not shown). The structure between the residues 101170 appeared to be a random coil. These secondary structures are consistent with known features of $\mathrm{SSB}_{\mathrm{EC}}$ monomer, as determined earlier by $\mathrm{X}$-ray crystallography $[37,39,42]$.

Alignment of $\mathrm{SSB}_{\mathrm{BA}}$ sequence with sequences of other prokaryotic SSBs did not provide any clue to the basis of 
its ssDNA binding properties (Figure 1). Therefore, the three-dimensional structure of $\mathrm{SSB}_{\mathrm{EC}}$ derived from $\mathrm{X}$ ray crystallography [37] was explored. The significant sequence homology of $\mathrm{SSB}_{\mathrm{BA}}$ with $E$. coli $\mathrm{SSB}$ allowed us to develop a putative three dimensional model of $\mathrm{SSB}_{\mathrm{BA}}$ using homology based modeling. The initial modeling was done using the SWISS-MODEL server [43,44]. Further refinement of the model by energy minimization was carried out using SYBYL 8.1 (Tripos Inc., St. Louis, MO) molecular modeling software using the SSB crystal structure, PDB ID: 1QVC, as the structure template [37]. The structures for E. coli $\mathrm{SSB}_{\mathrm{EC}}, 1 \mathrm{QVC}$ and $\mathrm{SSB}_{\mathrm{BA}}$ were visualized using PyMOL (The PyMOL Molecular Graphics System, Version 1.3, Schrödinger LLC). Structures of both SSBs are presented in PyMol in Figure 7.

SSB proteins are known to bind ssDNA through their oligonucleotide/oligosaccharide binding fold ( $\mathrm{OB}$ fold) as described by Murzin [38]. The OB fold is characterized by a $\beta$-barrel consisting of five $\beta$-strands capped by an $\alpha$-helix. Despite sequence differences between $\mathrm{SSB}_{\mathrm{BA}}$ and $\mathrm{SSB}_{\mathrm{EC}}$, the $\mathrm{OB}$ fold observed in $\mathrm{SSB}_{\mathrm{EC}}$ remained intact in $\mathrm{SSB}_{\mathrm{BA}}$ including the $\beta$-turn regions, particularly L45 between $\beta$ sheets 4 and 5 (Figure 7). It has been shown that the $\beta$ sheet 1 of $\operatorname{SSB}_{\mathrm{EC}}$ with the sequence VNKVILV is in the monomer-interface of the SSB $_{\mathrm{EC}}$ dimer [39]. In $\mathrm{SSB}_{\mathrm{BA}}$, this $\beta$ sheet remains partially intact (NKVILV) with the loss of the Val5 residue.
However, the His56 of one monomer in $\mathrm{SSB}_{\mathrm{EC}}$ forms a hydrogen bond with Asn6 and the carbonyl oxygen of Leu83 of another monomer, which is essential for a stable dimer/tetramer formation. Although Asn6 (Asn2 in $\mathrm{SSB}_{\mathrm{BA}}$ ) and Leu83 (Leu76 in $\mathrm{SSB}_{\mathrm{BA}}$ ) remained conserved, one of the most important residues, His56 in $\mathrm{SSB}_{\mathrm{EC}}$ was altered to Ile (Ile47) in $\mathrm{SSB}_{\mathrm{BA}}$ (Figure 1). It should be noted that in the temperature-sensitive $E$. coli mutant, ssb-1, His56 was mutated to Tyr56 leading to the $t s$-phenotype. E. coli ssb-1 ts-mutant does not form a stable tetramer at non-permissive temperature $[5,45]$. Thus, the lack of this His residue in $\mathrm{SSB}_{\mathrm{BA}}$ will likely hinder a stable dimer formation.

The $\mathrm{SSB}_{\mathrm{EC}}$ tetramer is formed by the interaction of two dimers $[37,39]$. The dimer-dimer interface involves two six-stranded surfaces, each comprised of $\beta 1, \beta 4$, and $\beta 5$ from two monomers. The structure of $\mathrm{SSB}_{\mathrm{BA}}$, as shown in Figure 7, could form such a tetramer interface, had it not been for the difficulty associated with the dimer formation. It has been shown with a number of SSB crystal structures that a network of hydrogen bonds among the side chains in this six-stranded interface is necessary for a stable tetramer formation. The residues that were shown to be important in $\mathrm{SSB}_{\mathrm{EC}}$ for this network of hydrogen bond formation are Lys8, Tyr79, Gln77, Glu81, and Gln111. Sequence comparison (Figure 1) between $\mathrm{SSB}_{\mathrm{EC}}$ and $\mathrm{SSB}_{\mathrm{BA}}$ indicated that all of

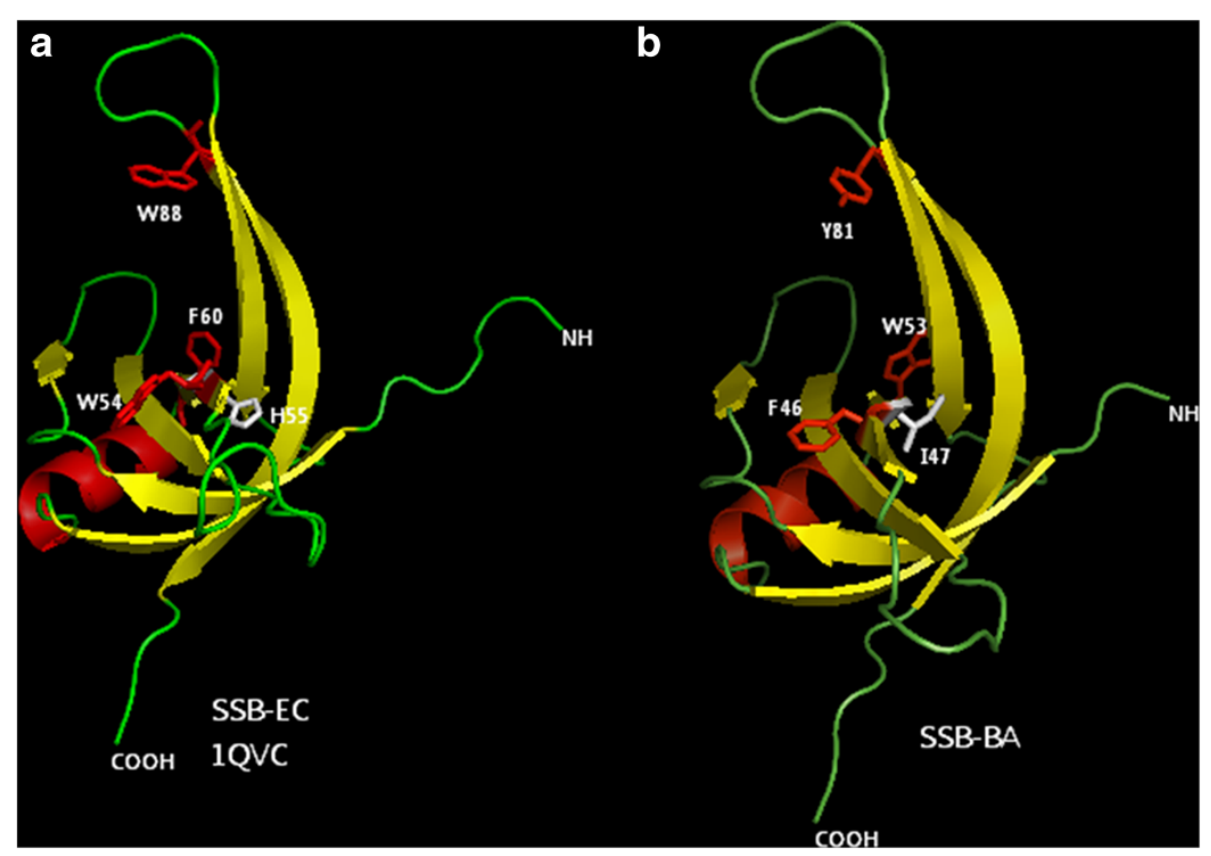

Figure 7 Homology based modeling of $\mathrm{SSB}_{\mathrm{BA}}$. (a) Model of the $\mathrm{SSB}_{\mathrm{EC}}$ derived from the crystal structure of a chymotrypsin truncated $\mathrm{SSB}_{\mathrm{EC}}$ monomer lacking 42 C-terminal residues (PDB ID 1QVC). (b) Model of the SSB $B_{B A}$ derived from the crystal structure SSBEC monomer (PDB ID $1 \mathrm{QVC})$. Both of these structures were generated using PyMol. In SSBEC, Trp55, Trp89, and Phe61 are important in the ssDNA binding, which are replaced by Phe47, Tyr82, and Trp53 respectively in SSB $\mathrm{BA}_{\mathrm{B}}$. Most notably, His56 residue of SSB $\mathrm{EC}$, required for monomer-monomer interaction is replaced by lle48 in SSB $B_{B A}[39]$. 
these residues in $\mathrm{SSB}_{\mathrm{BA}}$ underwent changes and are as follows: Lys8 $\rightarrow$ Arg2, Tyr79 $\rightarrow$ Gly71, Gln77 $\rightarrow$ Leu69, Gln83 $\rightarrow$ Arg75, and Gln111 $\rightarrow$ Phe104. Although all of the changes may not be significant, three of these five changes are significant in terms of hydrogen bond formation. Therefore, these amino acid changes in $\mathrm{SSB}_{\mathrm{BA}}$ are likely to impede tetramer formation further. Taken together, inhibition of both monomer-monomer interaction leading to dimer formation as well as dimerdimer interaction leading to tetramer formation, the amino acid sequence of $\mathrm{SSB}_{\mathrm{BA}}$ does not support formation of stable dimer or tetramer.

\section{Analysis of the structure of ssDNA binding pocket in $\mathrm{SSB}_{\mathrm{BA}}$}

Single-stranded DNA binding by prokaryotic SSBs has been shown by several groups to be carried out exclusively by tetrameric forms of SSBs containing four OB folds or dimeric forms with each monomer containing two $\mathrm{OB}$ folds $[37,39,46]$. Thus, the presence of four $\mathrm{OB}$ folds in SSBs appears essential for high affinity ssDNA binding. Our studies indicated that $\mathrm{SSB}_{\mathrm{BA}}$ bound ssDNA with very high affinity $\left(1.0 \pm 0.1 \times 10^{-9} \mathrm{M}\right)$ even though it did not appear to form a stable tetramer in the absence of DNA at the concentration range examined (Figures $3 \& 7$ ).

The amino acid residues in $\mathrm{SSB}_{\mathrm{BA}}$ that are homologous to the residues in other SSBs, particularly $\mathrm{SSB}_{\mathrm{EC}}$, that are known from crystallographic studies to bind to ssDNA were analyzed. Several hydrophobic residues, Trp89, Trp55, and Phe61, in $\mathrm{SSB}_{\mathrm{EC}}$ have been identified as involved in ssDNA binding through base stacking interactions [39]. In Helicobacter pylori SSB ( $\left.\mathrm{SSB}_{\mathrm{HP}}\right)$, Phe37, Phe50, Phe56, and Trp84 are involved in base stacking interactions with ssDNA [47]. These hydrophobic residues (Phe36, Phe43, Trp53, and Tyr81) with changes remained conserved in $\mathrm{SSB}_{\mathrm{BA}}$ (Figure 1). As shown in Figure 8, these aromatic side chains are exposed in the DNA binding groove of the OB fold so that ssDNA bases could have stacking interactions. In addition, ssDNA binding to SSB requires a large number of positively charged residues for the formation of ionic bridges with the phosphodiester backbone of ssDNA. A large number of Arg and Lys residues were observed in and around the groove as shown in Figure 8. Among these, Arg9, Lys12, Arg17, Arg42, Arg54, Lys55, Lys65, Lys66, Lys87, Arg88, Arg103 appeared to be in close proximity of the DNA binding groove and form ionic bridges with the phosphodiester backbone. Consequently, the high affinity ssDNA binding observed with $\mathrm{SSB}_{\mathrm{BA}}$ could be due to basic as well as aromatic residues in its DNA binding groove.

\section{Subunit structure of $\mathrm{SSB}_{\mathrm{BA}}$ in the $\mathrm{SSB}_{\mathrm{BA}} \cdot \mathrm{SSDNA}$ complex}

Our studies demonstrated that $\mathrm{SSB}_{\mathrm{BA}}$ was capable of highaffinity binding of ssDNA. Was it possible that the protein could form higher order structures, possibly tetramers, upon binding long ssDNA templates? Tetrameric E. coli SSB binds ssDNA in two distinguishable forms; $\mathrm{SSB}_{35}$ and $\mathrm{SSB}_{65}[26,48]$. The $\mathrm{SSB}_{35}$ form binds approximately $35 \mathrm{nt}$ and the $\mathrm{SSB}_{65}$ form binds approximately $65 \mathrm{nt}$ on a $(\mathrm{dT})_{70}$

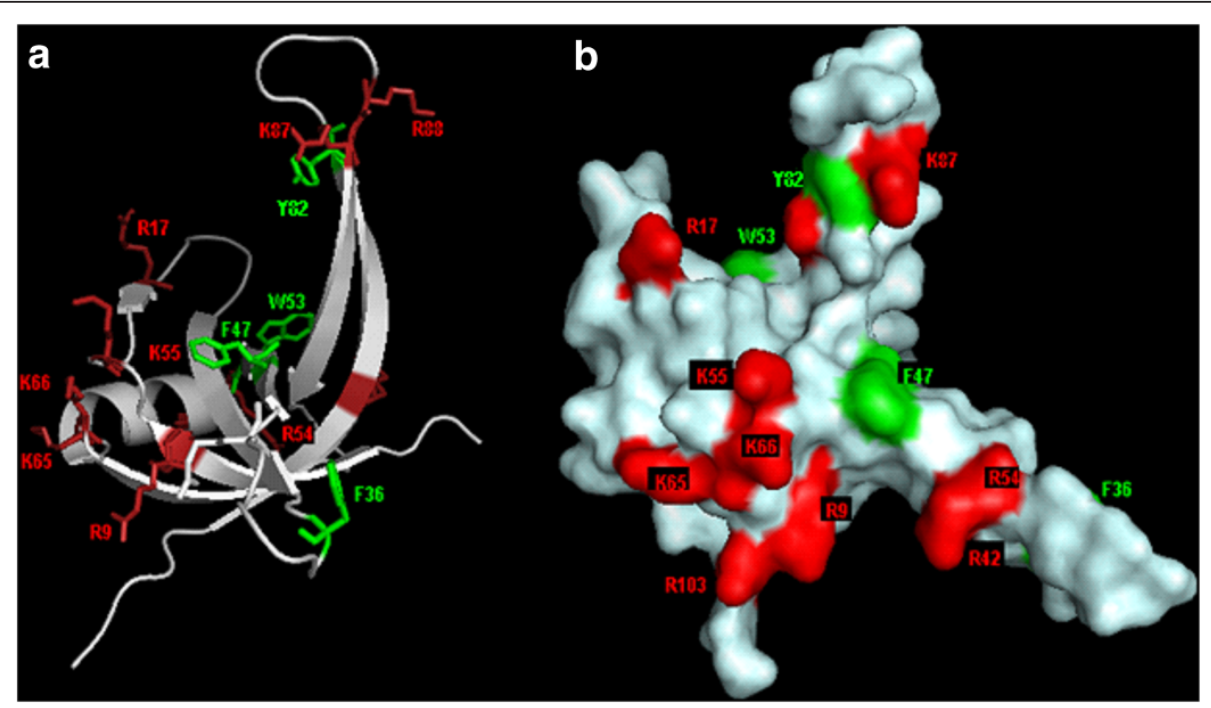

Figure 8 Surface topology and charge distribution on the surface of $\mathrm{SSB}_{\mathrm{BA}}$ that are involved in ssDNA binding. Hydrophobic (in green) and basic residues (in red) that are likely involved in ssDNA binding are depicted. (a) Hydrophobic residues (Phe36, Phe47, Trp53, and Tyr82) are depicted in green sticks and basic residues (Arg 9, 17, 54,88 and Lys 55, 65, 66, 87) are presented in red sticks attached to the backbone.

(b) Electrostatic surface potential of the $\mathrm{SSB}_{\mathrm{BA}}$ are created from the structure in Figure 7A using the program PyMOL. Hydrophobic, positive, and neutral potential surface are displayed and colored green, red, and white, respectively. 
template. In the $\mathrm{SSB}_{35}$ form, only two subunits of the tetramer make contacts with the DNA, whereas, in $\mathrm{SSB}_{65}$ form all four subunits of the tetramer make contacts with the DNA. These two forms can be distinguished by fluorescence resonance energy transfer (FRET) using a long ssDNA labeled in each end with $\mathrm{Cy} 3$ and $\mathrm{Cy} 5$ fluorophores [26]. The $\mathrm{SSB}_{65}$ form produces high FRET and the $\mathrm{SSB}_{35}$ form produces attenuated FRET. This approach was utilized using a seventy nucleotide, $(\mathrm{dT})_{70}$, oligonucleotide labeled with a 3' Cy3 fluorophore and a 5' Cy5 fluorophore $\left(\mathrm{Cy} 5-(\mathrm{dT})_{70}-\mathrm{Cy} 3\right)$ to test our hypothesis that $\mathrm{SSB}_{\mathrm{BA}}$ forms higher order structures upon DNA binding. With this ssDNA substrate, we anticipated that $\mathrm{SSB}_{\mathrm{BA}}$ in $\mathrm{SSB}_{35^{-}}$ mode would produce attenuated FRET and $\mathrm{SSB}_{65}$-mode would produce high FRET. Binding of $\mathrm{SSB}_{\mathrm{EC}}$ to Cy5$(\mathrm{dT})_{70}$-Cy3 oligonucleotide was first analyzed to test the validity of our assay. The results are presented in Figure 9. FRET was measured using $515 \mathrm{~nm}$ excitation wavelength and $665 \mathrm{~nm}$ emission wavelength. The emission intensity was corrected for $\mathrm{Cy} 5$ contribution to $665 \mathrm{~nm}$ emission. FRET was defined by $\left(F-F_{0}\right) / F_{0}$ where $F_{0}$ and $F$ are the corrected $665 \mathrm{~nm}$ emission intensities of the $200 \mathrm{nM} 5^{\prime}$-Cy5 $(\mathrm{dT})_{70} \mathrm{Cy} 3-3$ ' oligonucleotide in the absence and presence of SSB respectively. In the titration with $\mathrm{SSB}_{\mathrm{EC}}$, sharp increase in FRET with initial titration with $\mathrm{SSB}_{\mathrm{EC}}$ reaching a peak at $0.44 \mu \mathrm{M}$ concentration was seen. Upon further titration with $\mathrm{SSB}_{\mathrm{EC}}$, the FRET decreased substantially and reached a plateau at concentrations higher than $1.1 \mu \mathrm{M}$. These results with $\mathrm{SSB}_{\mathrm{EC}}$ are comparable to that observed by Roy et al. [26]. However, our experiments required a somewhat higher concentration of $\mathrm{SSB}_{\mathrm{EC}}$ than reported by Roy et al. [26], which could be due to different buffer systems and ssDNA concentration. Thus, at $0.44 \mu \mathrm{M} \mathrm{SSB} \mathrm{EC}_{\mathrm{EC}}$, the high FRET $\left(\mathrm{SSB}_{\mathrm{EC}}\right)_{4}-(\mathrm{dT})_{70}$ complex was observed and at or above $1.1 \mu \mathrm{M} \mathrm{SSB} \mathrm{EC}$, intermediate FRET $\left(\mathrm{SSB}_{\mathrm{EC}}\right)_{8^{-}}$ $(\mathrm{dT})_{70}$ complex was seen.

Next, $\mathrm{SSB}_{\mathrm{BA}}$ binding to $\mathrm{Cy} 5(\mathrm{dT})_{70} \mathrm{Cy} 3$ oligonucleotide was analyzed. The $\mathrm{Cy} 5(\mathrm{dT})_{70} \mathrm{Cy} 3$ oligonucleotide was titrated with $\mathrm{SSB}_{\mathrm{BA}}$ as described above for $\mathrm{SSB}_{\mathrm{EC}}$. Similar to $\mathrm{SSB}_{\mathrm{EC}}$, FRET increased linearly with increasing concentration of $\mathrm{SSB}_{\mathrm{BA}}$, and reached a plateau at $0.8 \mu \mathrm{M}$ Surprisingly, only a high FRET form of $\left(\mathrm{SSB}_{\mathrm{BA}}\right)-(\mathrm{dT})_{70}$ complex was observed. However, initial slope of the plot is very different from that observed with $\mathrm{SSB}_{\mathrm{EC}}$ which is a stable tetramer. Therefore, it appeared that the high FRET form of the complex was formed but required higher concentration of $\mathrm{SSB}_{\mathrm{BA}}$. The high FRET form of $\left(\mathrm{SSB}_{\mathrm{EC}}\right)-(\mathrm{dT})_{70}$ complex is a tetrameric complex in which all four monomers bind ssDNA. The high FRET form of $\left(\mathrm{SSB}_{\mathrm{BA}}\right)-(\mathrm{dT})_{70}$ complex should have the same oligomeric structure as the high FRET form of $\left(\mathrm{SSB}_{\mathrm{EC}}\right)$ $(\mathrm{dT})_{70}$ complex. As $\mathrm{SSB}_{\mathrm{BA}}$ lacked stable tetramer formation, it required higher ( $\sim$ two fold) SSB concentration to form the high FRET complex. The reason is that this

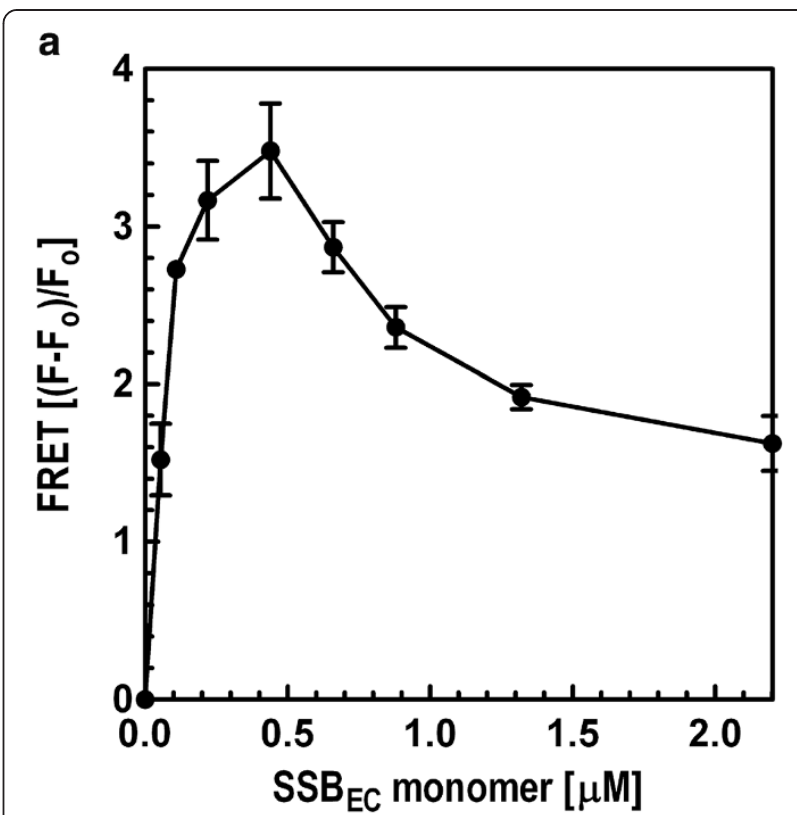

b

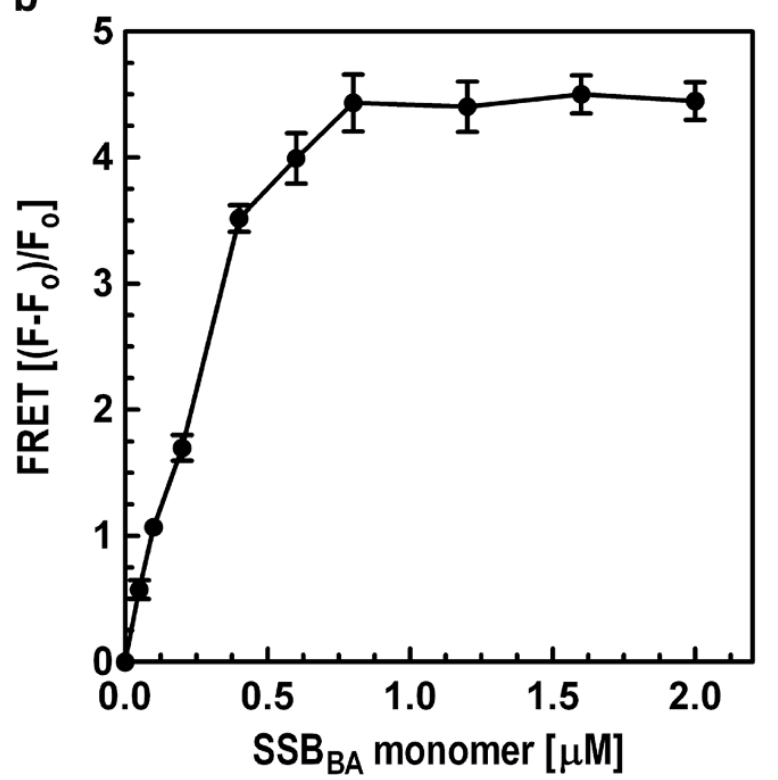

Figure 9 Analysis of binding modes, (SSB) ${ }_{35}$ and (SSB) 65 , of $\mathrm{SSB}_{\mathrm{EC}}$ and $\mathrm{SSB}_{\mathrm{BA}}$ by FRET analysis. Protein-SSDNA binding and FRET assays were carried out as described in Materials \& Methods [26]. The FRET substrate was $40 \mathrm{nM} 5^{\prime}-\mathrm{Cy} 5-(\mathrm{dT})_{70}-\mathrm{Cy} 3-3^{\prime}$. (a) Analysis of SSB $\mathrm{EC}_{\mathrm{EC}}$ binding to $5^{\prime}-\mathrm{Cy} 5-(\mathrm{dT})_{70} \mathrm{C}$-Cy3-3'. Both (SSB) 65 and (SSB) 35 modes are clearly observed (22). (b) Analysis of $\mathrm{SSB}_{\mathrm{BA}}$ binding to 5'-Cy5-(dT) $70-$ Cy3-3'. Only (SSB) 65 , not (SSB) 35 , mode was observed.

complex is not formed by a single binding event as is the case with $\mathrm{SSB}_{\mathrm{EC}}$ complex. It involves four binding and one structural rearrangement steps. As individual monomers are binding, there are four separate binding constants $(\mathrm{K} 1, \mathrm{~K} 2, \mathrm{~K} 3$, and $\mathrm{K} 4)$ involved in the $\left(\mathrm{SSB}_{\mathrm{BA}}\right)_{4^{-}}$ $(\mathrm{dT})_{70}$ complex formation. It will be erroneous to 
assume that they are all $1 \mathrm{nM}$. Certainly $\mathrm{K} 1$ is $1 \mathrm{nM}$ as observed in Figure 4. Other binding constants (K2, K3, and K4) are likely to be higher than $1 \mathrm{nM}$ due to steric hindrance which is particularly important for K4 involving the binding of the fourth monomer. The $(\mathrm{dT})_{70}$ is small and can accommodate only four $\mathrm{SSB}_{\mathrm{BA}}$ resulting in progressive lack of sufficient open DNA for second, third and fourth $\mathrm{SSB}_{\mathrm{BA}}$ monomers to bind. Therefore, it is very likely that $\mathrm{K} 2$ and $\mathrm{K} 3$ are higher and $\mathrm{K} 4$ is substantially higher than $1 \mathrm{nM}$ which explains a higher $\mathrm{SSB}_{\mathrm{BA}}$ concentration to achieve a high FRET complex. Based on this reasoning of the $\left(\mathrm{SSB}_{\mathrm{BA}}\right)_{4}-(\mathrm{dT})_{70}$ complex formation, as described above, our data actually supports the model in Figure 10. Lack of observation of an intermediate FRET form of the $\left(\mathrm{SSB}_{\mathrm{BA}}\right)-(\mathrm{dT})_{70}$ complex in this study indicated that a $\left(\mathrm{SSB}_{\mathrm{BA}}\right)_{8}-(\mathrm{dT})_{70}$ complex probably did not form in appreciable amount even with high proportional levels of $\mathrm{SSB}_{\mathrm{BA}}$. Based on these reasonings of the $\left(\mathrm{SSB}_{\mathrm{BA}}\right)_{4}-(\mathrm{dT})_{70}$ complex formation, as described above, our data led to the proposal of the model presented in Figure 10 for the $\left(\mathrm{SSB}_{\mathrm{BA}}\right)_{8}-(\mathrm{dT})_{70}$ complex.

\section{Discussion}

SSB protein is required for a variety of processes such as DNA replication, recombination and DNA repair despite its lack of any enzymatic activity [5,9,49]. Among its multifaceted cellular activities, a common feature of all of these processes is to bind ssDNA with high affinity and protect it from reannealing and/or degradation. Of emerging importance is SSB's role in protein-protein interaction during various DNA transactions. Most studies involving SSB proteins demonstrated that ssDNA wraps around a tetrameric form of SSB.

\section{$\mathrm{SSB}_{\mathrm{BA}}$ does not form a stable tetramer}

E. coli $\mathrm{SSB}_{\mathrm{EC}}$ is a stable tetramer with high solubility and tremendous thermal stability [1]. The majority of prokaryotic cellular SSBs are homotetramers, where each monomer harbors an $\mathrm{OB}$ fold. However there are exceptions. $\mathrm{SSB}_{\mathrm{DR}}$ from Deinococcus radiodurans is a homodimer, where each monomer is quite large and contains two OB folds [37-39,46]. Each OB fold is capable of binding ssDNA independently. In both cases, a stable $\mathrm{SSB}$ protein complex with four $\mathrm{OB}$ folds is required for ssDNA binding. $\mathrm{SSB}_{\mathrm{BA}}$ was found to be not tetrameric at or above ambient temperature by size exclusion HPLC (Figure 3). This physicochemical property of $\mathrm{SSB}_{\mathrm{BA}}$ is closely comparable to the $\mathrm{T} 4$ bacteriophage $\mathrm{SSB}$, which is monomeric.

\section{Molecular basis of $\mathrm{SSB}_{\mathrm{BA}}$ structure}

Sequence alignment and three dimensional structure of $\mathrm{SSB}_{\mathrm{BA}}$, generated by homology-based modeling were

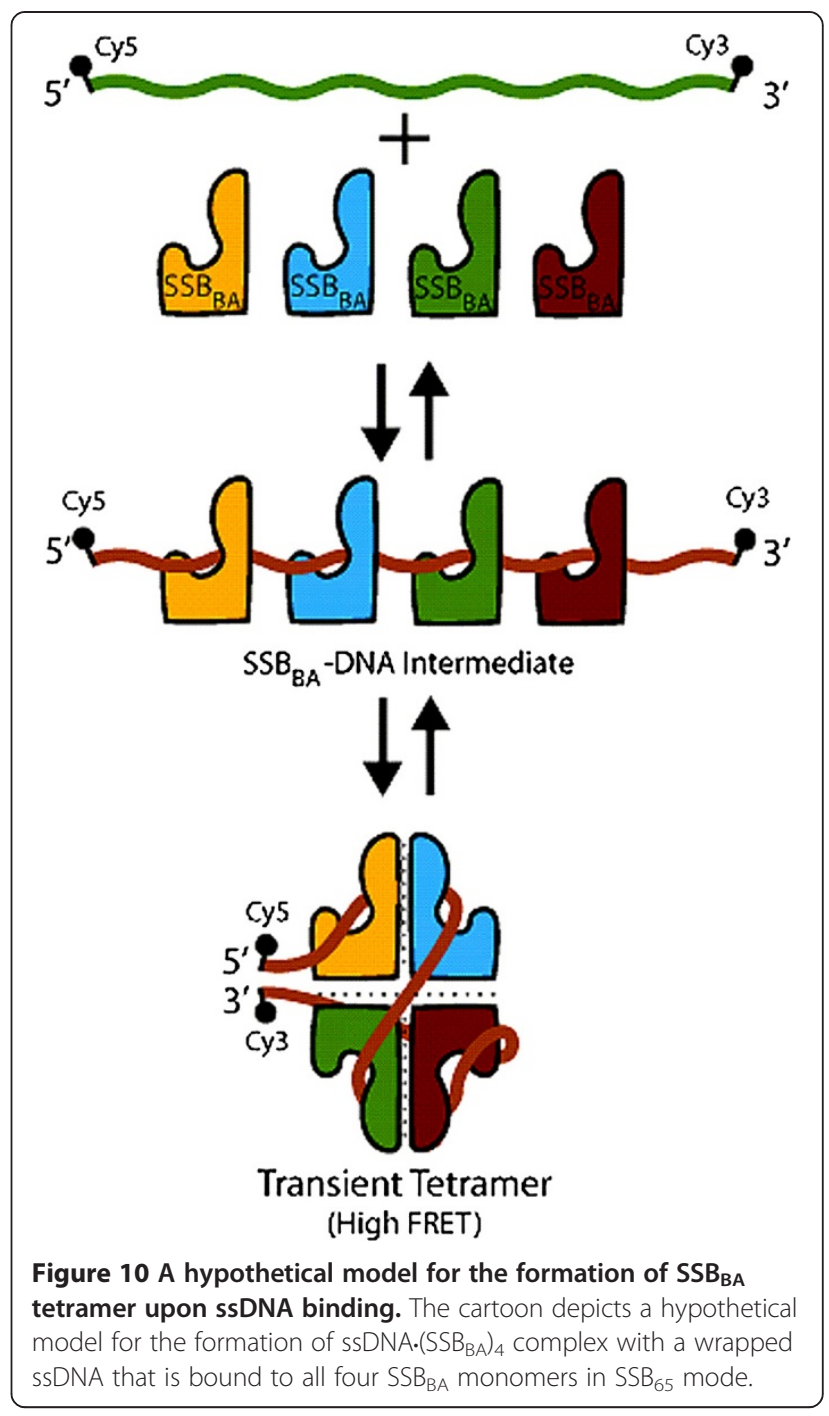

utilized to probe the molecular basis of ssDNA binding (Figures 1). Sequence alignment and secondary structure prediction (data not shown) clearly indicated the presence of an $\mathrm{OB}$ fold in $\mathrm{SSB}_{\mathrm{BA}}$, which is a characteristic of $\mathrm{SSBs}$ and required for high affinity ssDNA binding (Figure 4).

Both sequence alignment and homology modeling (Figures 1 \& 8) indicated lack of several residues that are important for monomer-monomer and dimer-dimer interactions leading to the formation of a stable tetramer in $\mathrm{SSB}_{\mathrm{EC}}$. His56 (as well as Glu54) of $\beta$ sheet 3 (Figure 1) in $\mathrm{SSB}_{\mathrm{EC}}$ plays an important role by forming a hydrogen bond with Asn7 in $\beta$ sheet 1 , the carbonyl group in Leu84 and Thr100 at the base of loop L45. Notably, in E. coli temperature-sensitive mutant, ssb-1, His56 is mutated to Tyr56 [5]. This mutant does not form a stable tetramer with respect to monomers at nonpermissive temperatures $[5,45,50]$. Thus, a lack of the 
corresponding His residue (His $\rightarrow$ Ile change) in $\mathrm{SSB}_{\mathrm{BA}}$ may be one of the important contributors to its structure. Moreover, in B. anthracis the sequence Glu54. Trp55.His56 in the E. coli $\beta$ sheet 3 is altered to Asp46. Phe47.Ile48 (Figure 1). This change did not alter the $\beta$ sheet structure but may have altered the contributions of these residues in the monomer-monomer interaction in the stable dimer and tetramer formation. It appears that although $\beta$ sheet 1 remained conserved in $\mathrm{SSB}_{\mathrm{BA}}$, this region lacks the valine residue which may have attenuated the interaction of the $\beta$ sheet 1 with $\beta$ sheet 1 ' in the monomer-monomer interface of the dimer. The shortening of the $\mathrm{N}$-terminus in $\mathrm{SSB}_{\mathrm{BA}}$ may also have deleterious effect in the interactions involving $\mathrm{H}$-bonds in this region and can contribute to the lack of tetramer formation. Taken together, the amino acid residue substitutions in $\mathrm{SSB}_{\mathrm{BA}}$, as described above, are likely contributed to the disruption of monomer-monomer interaction leading to dimer formation.

The dimer-dimer interface in the $\mathrm{SSB}_{\mathrm{EC}}$ tetramer is primarily a six-stranded $\beta$ sheet-mediated. Residues that are important in $\mathrm{SSB}_{\mathrm{EC}}$ for the network of hydrogen bond formation at the dimer-dimer interface are Lys8, Tyr71, Gln77, Glu81, and Gln111 [39]. Sequence comparison (Figure 1) between $\mathrm{SSB}_{\mathrm{EC}}$ and $\mathrm{SSB}_{\mathrm{BA}}$ indicated that all of these residues in $\mathrm{SSB}_{\mathrm{BA}}$ underwent alteration and are as follows: Lys8 $\rightarrow$ Arg3, Tyr79 $\rightarrow$ Gly71, Gln77 $\rightarrow$ Leu69, Gln83 $\rightarrow$ Arg75, and Gln111 $\rightarrow$ Phe104. Some of these changes are chemically significant leading to possible disruption of the network of hydrogen bond formation that is required for a stable tetramer formation. In addition, Gln77 and Gln111 are located in the dimer-dimer interface and have been implicated in the tetramer formation. As described earlier, Gln111 is altered to Phe104 in $\mathrm{SSB}_{\mathrm{BA}}$. An equally significant change is observed with Gln77 which is changed to Leu69 in $\mathrm{SSB}_{\mathrm{BA}}$. Taken together, these changes in amino acid sequence may disrupt both monomer-monomer and dimer-dimer interactions leading to a monomeric $\mathrm{SSB}_{\mathrm{BA}}$ at a physiological temperature.

\section{Energetics of $\mathrm{SSB}_{\mathrm{BA}} \cdot$ ssDNA binding}

Protein-DNA recognition and binding involve complex interactions. Earlier, we have used fluorescence anisotropy analysis of DNA binding by $E$. coli DNA primase and determined the thermodynamic parameters of protein-DNA interaction (38). We have used a similar analysis to probe the ssDNA binding by $\mathrm{SSB}_{\mathrm{BA}}$. In addition, we have analyzed contribution of electrostatic and ionic interactions in the binding by analyzing the dependence of binding on the ionic strength of the environment. Together, these two analyses provided a detailed picture of the forces in $\mathrm{SSB}_{\mathrm{BA}} \cdot \mathrm{Ss} \mathrm{DNA}$ binding.
The $K_{D}$ values were determined at different temperatures $\left(20-37^{\circ} \mathrm{C}\right)$ (Figure 5). Our data showed that although $\mathrm{SSB}_{\mathrm{BA}}$ was able to bind DNA at a wide range of temperatures, it bound with the highest affinity at $20-25^{\circ} \mathrm{C}$. The free energy change for SSB.ssDNA association was $-23 \mathrm{~kJ} \mathrm{~mol}^{-1}$ at $25^{\circ} \mathrm{C}$. Using the two equations: $\Delta \mathrm{G}^{\circ}=$ $-\mathrm{RT} \ln K_{\mathrm{D}}$ and $\Delta \mathrm{G}^{\circ}=\Delta \mathrm{H}^{\circ}-\mathrm{T} \Delta \mathrm{S}^{\circ}$ and the slope of the plot, we determined that $\Delta S^{\circ}$ was $\sim 188 \mathrm{~J} \mathrm{~mol}^{-1} \mathrm{~K}^{-1}$ in this temperature range.

We determined the $K_{D}$ value of $\mathrm{SSB}_{\mathrm{BA}}$ binding to ssDNA at different salt concentrations (0-200 mM $\mathrm{NaCl}$ ) (Figure 6A). The binding is progressively weakened with an increase in ionic strength. The $K_{D}$ values were then analyzed using a linkage plot to determined ionic interactions in the binding. The negative slope of the plot in Figure 5B indicated a release of ions from. Our analysis determined the release of one $\mathrm{Na}^{+}$and one $\mathrm{Cl}^{-}$ion during the binding process. In addition, our results also pointed out that $\mathrm{SSB}_{\mathrm{BA}}$ likely formed a tetrameric species at $0 \mathrm{mM} \mathrm{NaCl}$ and became monomeric at higher $\mathrm{NaCl}$ concentration. It is perhaps possible that the tetramer formation could be dependent on the ionic strength.

Thus our results suggest that ionic interaction or salt bridge formation between the protein and the DNA made specific contribution to the overall free energy change. In order to determine the contribution we first extrapolated $K_{D}$ value of the complex at infinite salt concentration $\left(\mathrm{K}_{\mathrm{D}}^{\infty}\right)$ by nonlinear regression of $\mathrm{K}_{\mathrm{D}}$ versus $\log [\mathrm{NaCl}]$ plot (data not shown). The value of $\Delta G^{\circ}$ ionic was $-8 \mathrm{~kJ} \mathrm{~mol}^{-1}$.

\section{Mechanisms of ssDNA binding by $\mathrm{SSB}_{\mathrm{BA}}$}

Despite differences between its Gram-negative counterpart, $\mathrm{SSB}_{\mathrm{BA}}$ bound to ssDNA with high affinity (Figure 4). The ssDNA binding affinity $\left(\mathrm{K}_{\mathrm{D}}\right)$ for a $\mathrm{SSB}_{\mathrm{BA}}$ monomer binding to a small oligonucleotide was $1.0 \pm 0.1 \times 10^{-9} \mathrm{M}$ at $25^{\circ} \mathrm{C}$. Even though many changes in amino acid sequence of $\mathrm{SSB}_{\mathrm{BA}}$ directly relate to ssDNA binding, such as Trp55 $\rightarrow$ Phe47, Trp90 $\rightarrow$ Tyr81, Phe61 $\rightarrow$ Trp53, the changes are not drastic enough to alter ssDNA binding (Figure 8). Three dimensional structure as well as electrostatic surface potential in Figure 8 indicates that ssDNA binding remained unperturbed. A temperature-sensitive mutant of $E$. coli SSB, $s s b-1$, is unable to form a stable tetramer at a non-permissive temperature $[5,45,50]$. This mutant is also defective in supporting DNA replication at non-permissive temperature. Thus, it appears a SSB tetramer formation is a prerequisite for DNA replication. Consequently, we sought to explore whether ssDNA template could influence the ability of $\mathrm{SSB}_{\mathrm{BA}}$ to form tetramers upon DNA binding. A likely possibility is that $\mathrm{SSB}_{\mathrm{BA}}$ is capable of forming a normal tetrameric structure containing four OB-folds, as seen in other SSBs, upon sufficiently 
long ssDNA. This possibility was examined using a recently developed FRET assay for SSB.ssDNA interaction [26].

Previous studies with $\mathrm{SSB}_{\mathrm{EC}}$ have shown that its $\mathrm{SSB}_{35}$ and $\mathrm{SSB}_{65}$ binding modes can be distinguished by a FRET assay [26]. Both of these ssDNA binding modes require a tetrameric (or di-tetrameric) structure of bound SSB. A similar FRET assay was used to probe the structure of $\mathrm{SSB}_{\mathrm{BA}}$ in ssDNA bound state. As the ssDNA binding constant of $\mathrm{SSB}_{\mathrm{BA}}$ is very high, the possibility that it may form a tetramer only in the ssDNA bound state was investigated. As shown in Figure 9A, $\mathrm{SSB}_{\mathrm{EC}}$ formed both $\mathrm{SSB}_{35}$ and $\mathrm{SSB}_{65}$ structures with the $5^{\prime}-\mathrm{Cy} 5$ $(\mathrm{dT})_{70} \mathrm{Cy} 3-3^{\prime}$ oligonucleotide as evidenced by FRET analysis. As described earlier, $\mathrm{SSB}_{35}$ represented the intermediate-FRET complex and $\mathrm{SSB}_{65}$ represented the high-FRET SSB-ssDNA complex. At a low SSB to $\mathrm{dT}_{70}$ ratio, it formed the high FRET complex and at a high $\mathrm{SSB}$ to $\mathrm{dT}_{70}$ ratio, it formed the intermediate FRET complex. In the FRET analysis, $\mathrm{SSB}_{\mathrm{BA}}$ formed only a highFRET complex but not the intermediate-FRET complex (Figure 9B). In addition, the slope of the plot with $\mathrm{SSB}_{\mathrm{BA}}$ is different from that of $\mathrm{SSB}_{\mathrm{EC}}$. As $\mathrm{SSB}_{\mathrm{EC}}$ is a stable tetramer, the high FRET complex formed rapidly with increasing SSB concentration and it formed much slowly with $\mathrm{SSB}_{\mathrm{BA}}$ because of the lack of a stable tetramer formation. Our results appeared to indicate (i) a tetrameric structure of $\mathrm{SSB}_{\mathrm{BA}}$ in the $\mathrm{SSB}_{\mathrm{BA}}$-SSDNA complex, and

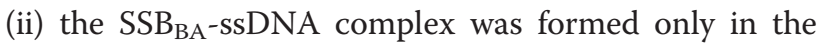
$\mathrm{SSB}_{65}$ mode. Due to high affinity of ssDNA binding, perhaps four monomers can bind the oligo $(\mathrm{dT})_{70}$ prior to the tetramer formation. Once this multi-SSB ${ }_{B A}$ complex is formed, the bound $\mathrm{SSB}_{\mathrm{BA}}$ monomers undergo conformational transition and form tetrameric structure in $\mathrm{SSB}_{65}$ mode. A hypothetical model is proposed in Figure 10. In this proposed model, all four monomers in the tetramer would first bind to the ssDNA, which would likely lead to the formation of the $\mathrm{SSB}_{65}$ complex and prevent the formation of a $\mathrm{SSB}_{35}$ complex. In the case of $\mathrm{SSB}_{\mathrm{BA}}$, a two-fold higher concentration of protein was needed to observe the high-FRET complex. We believe this is due to the following reasons. First, the $\mathrm{SSB}_{\mathrm{BA}}$ is in essence a mutant form of $\mathrm{SSB}_{\mathrm{EC}}$ and as a result its ssDNA binding mechanism is likely somewhat different. Second, higher concentration of $\mathrm{SSB}_{\mathrm{BA}}$ might have favored the binding of all four monomers to the ssDNA. Initial slope of the plot in Figure 9B appeared to support this pathway.

$\mathrm{SSB}_{\mathrm{BA}}$ appears to undergo structural transformations which may support its high affinity binding to ssDNA. Its structure is due to a cumulative effect of multiple changes in key amino acid residues in its sequence which resulted in the loss of stable tetramer formation. Nonetheless, the $\mathrm{SSB}_{\mathrm{BA}}$ bound oligo $(\mathrm{dT})_{20}$ with high affinity as shown in Figures 4, 5, 6. Therefore, multiple monomers will bind to oligo $(\mathrm{dT})_{70}$ due to its long size. Thus, it is reasonable to assume that four monomers are binding to a long ssDNA ( $\geq 70$ nucleotides). FRET data presented in Figure 9 established that $\mathrm{SSB}_{65}$-like structure is being formed upon oligo $(\mathrm{dT})_{70}$ binding. Therefore, the ssDNA binding is leading to the formation of an $\mathrm{SSB}_{65}$ complex in which ssDNA is bound to a $\mathrm{SSB}_{\mathrm{EC}^{-}}$ like tetrameric structure. We have proposed a hypothetical model, presented in Figure 10, which may explain the mechanism of formation of a $\mathrm{SSB}_{\mathrm{BA}}$ tetramer assembly upon ssDNA binding which require further studies of such complex formation. The proposed model represents a stepwise process by which $\mathrm{SSB}_{\mathrm{BA}}$ can achieve high affinity DNA binding through a tetramer formation. This mechanism of SSB-ssDNA complex formation and its reversal may aid in the rapid removal of SSB, a necessary step, by enzymes such as a DNA polymerase during DNA replication as well as in other processes. In essence, $\mathrm{SSB}_{\mathrm{BA}}$ could actually be more effective than its tetrameric orthologs in executing its multifaceted functions in cellular DNA transactions.

\section{Conclusions}

Our studies suggest that the structural properties of $\mathrm{SSB}_{\mathrm{BA}}$ differ from that of its Gram-negative counterpart, $\mathrm{SSB}_{\mathrm{EC}}$, and that furthermore its structure is modulated in the presence an ssDNA template. It is noteworthy that despite complexities in structure and oligomerization, $\mathrm{SSB}_{\mathrm{BA}}$ retains high-affinity ssDNA binding, which is its primary function. Its unique structure may be due to the cumulative effect of multiple key amino acid changes in its sequence during evolution, leading to alteration of stable dimer and tetramer formation. In the presence of a long ssDNA ( $\geq 70$ nucleotides) appears to form with $\mathrm{SSB}_{\mathrm{BA}}$ a $\mathrm{SSB}_{65}$ complex in which ssDNA is bound to all four SSB monomers in a tetrameric structure. A proposed model

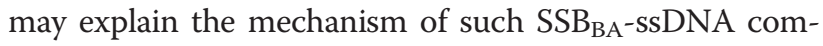
plex formation through a transient tetramer formation. This model indicates that $\mathrm{SSB}_{\mathrm{BA}}$ may be more efficient in assembly and disassembly of the protein-DNA complex particularly during DNA replication. The physiological consequence(s) of the unusual structural dynamics of $\mathrm{SSB}_{\mathrm{BA}}$, could be significant. Further studies are required to fully elucidate the role of protein.DNA and protein.protein interactions on $\mathrm{SSB}_{\mathrm{BA}}$ protein structure.

\section{Methods}

\section{Nucleic acids and other reagents}

Ultra pure nucleotides were obtained from GE Biosciences (Piscataway, NJ) and were used without further purification. All other chemicals used to prepare buffers and solutions were reagent grade and were purchased from the Fisher Chemical Company (Pittsburgh, PA). 
HPLC ion exchange columns, ion exchange chromatography matrix, and the Bio-Cad 20 HPLC instrument were from Applied Biosystems Inc., Woburn, MA. The gel filtration column, TSK gel 3000SW, was from Tosoh Bioscience, King of Prussia, PA. Custom oligonucleotides for PCR and fluorescently labeled oligonucleotides were from Sigma-Aldrich (St. Louis, MO).

\section{Buffers}

Lysis buffer contained $25 \mathrm{mM}$ Tris- $\mathrm{HCl}$, (pH 7.9), 10\% sucrose, $250 \mathrm{mM} \mathrm{NaCl}$, and $0.001 \% \mathrm{NP} 40$. Buffer A contained $25 \mathrm{mM}$ Tris- $\mathrm{HCl}$ (pH 7.5), $5 \mathrm{mM} \mathrm{MgCl}_{2}, 10 \%$ glycerol, $5 \mathrm{mM} \mathrm{DTT}$, and $\mathrm{NaCl}$ in $\mathrm{mM}$ as indicated in the subscript. Buffer B, used for all fluorescence studies, contained $20 \mathrm{mM}$ Hepes- $\mathrm{NaOH}$ (pH 7.5), $5 \mathrm{mM} \mathrm{MgCl}$ and $1 \mathrm{mM}$ DTT and $25 \mathrm{mM}$ (unless otherwise indicated) ultrapure $\mathrm{NaCl}$. In temperature and salt titration experiments, buffer B containing 5\% ultrapure glycerol was used. Buffers for fluorescence measurements were prepared with HPLC-grade water (with minimal background fluorescence), fluorescence grade reagents, and filtered through a $0.2 \mu \mathrm{m}$ nylon filter, examined for background fluorescence and Raman spectrum before use in anisotropy measurements. Background fluorescence was subtracted where necessary.

\section{Cloning and expression of $\mathrm{SSB}_{\mathrm{BA}}$}

The $\mathrm{SSB}_{\mathrm{BA}}$ gene was amplified by PCR using $B$. anthracis genomic DNA, obtained as a gift from Dr. Theresa $\mathrm{M}$. Koehler of the University of Texas Houston Health Science Center, Houston $(33,34)$. This ORF codes for a 172 amino acid polypeptide with a predicted molecular weight of $19.2 \mathrm{kDa}$. The amplified gene was cloned into a pET29b vector (Novagen, Inc., Madison, WI) under the control of a T7 promoter (pET29b-SSB ${ }_{B A}$ recombinant plasmid). The presence of the correct insert was confirmed by DNA sequencing. The $\mathrm{SSB}_{\mathrm{BA}}$ protein was over-expressed in $E$. coli strain BL21(DE3)RIL (Agilent Technologies Inc., Santa Clara, CA) harboring pET29b-SSB BA $_{\text {p }}$ plasmid. Cells harboring the recombinant plasmid were grown in $2 \mathrm{X}-\mathrm{YT}$ media containing $50 \mu \mathrm{g} / \mathrm{ml}$ of kanamycin, $20 \mu \mathrm{g} / \mathrm{ml}$ of tetracycline and $12 \mu \mathrm{g} / \mathrm{ml}$ of chloramphenicol with shaking at $37^{\circ} \mathrm{C}$ to an optical density at $600 \mathrm{~nm}$ of 0.4 . IPTG (isopropyl- $\beta$-D-thiogalactopyranoside) was added to a final concentration of $0.25 \mathrm{mM}$. The cells were shaken for an additional two hours at $25^{\circ} \mathrm{C}$, then harvested by centrifugation for $10 \mathrm{~min}$ at $5,000 \times \mathrm{g}$. The cells were resuspended in $2.5 \%$ of the original culture volume of lysis buffer at $4^{\circ} \mathrm{C}$ and stored at $-80^{\circ} \mathrm{C}$ until further use.

\section{Purification of $\mathrm{SSB}_{\mathrm{BA}}$}

Cells were thawed, adjusted to $\mathrm{pH} 8.0$ with $1 \mathrm{M}$ Tris base, and lysed using $0.25 \mathrm{mg} / \mathrm{ml}$ lysozyme, $5 \mathrm{mM}$ $\mathrm{MgCl}_{2}, 5 \mathrm{mM}$ spermidine $\cdot \mathrm{HCl}$, and $2.5 \mathrm{mM}$ DTT via incubation at ambient temperature for $60 \mathrm{~min}$. The mixture was Dounce homogenized followed by centrifugation. The lysate was centrifuged at $43,000 \mathrm{x} \mathrm{g}$ for $30 \mathrm{~min}$ at $23^{\circ}$ C. The supernatant was precipitated overnight using $0.25 \mathrm{~g} / \mathrm{ml}$ ammonium sulfate at $4^{\circ} \mathrm{C}$. This precipitate was collected by centrifugation at $43,000 \times \mathrm{g}$ for $30 \mathrm{~min}$ at $4^{\circ} \mathrm{C}$, and dissolved in buffer $\mathrm{A}_{0}$ (Fraction II). Fraction II was clarified by centrifugation at $43000 \mathrm{x}$ g for $30 \mathrm{~min}$. All steps were carried out at ambient temperature unless otherwise indicated.

The salt concentration of Fraction II was adjusted to the conductivity of buffer $A_{50}$ by diluting with buffer $\mathrm{A}_{0}$. The protein fraction was then passed through a $5 \mathrm{ml}$ POROS-Q column equilibrated with buffer $\mathrm{A}_{50}$. $\mathrm{SSB}_{\mathrm{BA}}$ protein was eluted with a $150 \mathrm{ml}$ gradient from $\mathrm{A}_{100}$ to $\mathrm{A}_{500}$. The $\mathrm{SSB}_{\mathrm{BA}}$ fractions, identified by SDSPAGE, were pooled (fraction III). The salt concentration of Fraction III was adjusted to the conductivity of buffer $\mathrm{A}_{50}$ by diluting with buffer $\mathrm{A}_{0}$. Diluted Fraction III was bound to a $5 \mathrm{ml} \mathrm{S}$-Sepharose column equilibrated with $A_{50} . S_{S B}$ was eluted using a $150 \mathrm{ml}$ gradient from $A_{100}$ to $A_{500}$. Fractions containing $\mathrm{SSB}_{\mathrm{BA}}$ were identified by SDS-PAGE and combined (Fraction IV). The Fraction IV, adjusted to $0.25 \mathrm{~g} / \mathrm{ml}$ ammonium sulfate, was incubated on ice for two hours that resulted in the selective precipitation of $\mathrm{SSB}_{\mathrm{BA}}$. The $\mathrm{SSB}_{\mathrm{BA}}$ precipitate was collected by centrifugation at $43000 \mathrm{xg}$ for $60 \mathrm{~min}$ at $0-1^{\circ} \mathrm{C}$. The pellet (Fraction V) was resuspended in $10 \mathrm{ml}$ of buffer $\mathrm{A}_{100}$. Homogeneity was assessed by SDS-PAGE.

\section{Assay of SSB biological activity}

The standard assay, based on the stimulation of DNA helicase ativity of DnaB protein, was carried out in $1 \mathrm{ml}$ of buffer B containing $1 \mathrm{mM}$ DTT, $25 \mathrm{mM} \mathrm{KCl}, 3.5 \mathrm{mM}$ ATP and $4.2 \mathrm{nmol}$ of the 55 bp partial duplex substrate containing the following oligonucleotides [51]:

\section{5'-GTCTTTCTGAGTACGAGAGTTCTGAGCAGTT CCAATACATTTTTTTTTTTTTTTT[Cy5]-3' \\ $5^{\prime}$-[Cy3] TTTTTTTTTTTTTTTATGTATTGGAACTG CTCAGAACTCTCGTACTCAGAAAGAC-3'}

Italicized nucleotides denote non-complimentary bases that create the fork structure of the duplex. Fluorescence emission spectra of the samples, before and after reaction, were recorded between $550-750 \mathrm{~nm}$ with $519 \mathrm{~nm}$ excitation with $8 \mathrm{~nm}$ slit-width. Reaction was initiated by adding $0.5 \mu \mathrm{g} / \mathrm{ml} \mathrm{DnaB}_{\mathrm{BA}}$ helicase to the reaction mixture and incubated for $15 \mathrm{~min}$ at $37^{\circ} \mathrm{C}$ and FRET was measured. $\operatorname{SSB}_{\mathrm{BA}}(3 \mu \mathrm{g} / \mathrm{ml})$ was added to the reaction mixture where indicated. $\mathrm{DnaB}_{\mathrm{BA}}$ helicase unwinding of the duplex led to inhibition of the FRET between $\mathrm{Cy} 3$ and $\mathrm{Cy} 5$. $\mathrm{SSB}_{\mathrm{BA}}$ was required for efficient helicase action of $\mathrm{DnaB}_{\mathrm{BA}}$ which was the basis of the assay. By 
using native and heat denatured substrates, it was determined that $1 \%$ decrease in FRET is equivalent to 3 pmol DNA unwinding in terms of base pairs (bp).

\section{Steady-state fluorescence measurements}

Fluorescence anisotropy was measured to investigate DNA binding by $\mathrm{SSB}_{\mathrm{BA}}$ in solution $[40,52]$. Fluorescence measurements were carried out using a steadystate-photon counting spectrofluorometer, PC1 with Vinci software, from ISS Instruments (Champaign, IL) and Fluoromax4-TCSPC with time-resolved fluorescence from Horiba Instruments Inc. (Edison, NJ). Excitation and emission slits were adjusted to $8 \mathrm{~nm}$ to maximize intensity counts [53]. Temperature during measurements was maintained using a programmable Peltier-controlled cuvette holder from Quantum Northwest Inc. (Seattle, WA).

\section{Fluorescence anisotropy analysis of equilibrium ssDNA binding}

The oligonucleotide was diluted to a concentration of $1 \mathrm{nM}$ and titrated with $\mathrm{SSB}_{\mathrm{BA}}$ within a concentration range of $0.1 \mathrm{nM}$ to $1 \mu \mathrm{M}$. The sample was incubated for 2 min after each addition and thermostated at $25^{\circ} \mathrm{C}$. Anisotropy measurements were carried out in general as described above except the excitation wavelength was $480 \mathrm{~nm}$ and emission anisotropy was measured at $540 \mathrm{~nm}$. The standard deviation for the anisotropy values was $<5 \mathrm{~mA}$. Anisotropy at each titration point was measured three times for $10 \mathrm{~s}$. and averaged. The total fluorescence intensity did not change significantly $(\leq 10 \%)$ with increase in $\mathrm{SSB}_{\mathrm{BA}}$ concentration. Therefore, fluorescence lifetime changes, or the scattered excitation light, did not affect the anisotropy measurements.

$$
\begin{aligned}
& \text { Anisotropy, } \mathrm{A}, \text { is defined as : A } \\
& =\left(\mathrm{I}_{\mathrm{vv}}-\mathrm{G} \times \mathrm{I}_{\mathrm{vh}}\right) /\left(\mathrm{I}_{\mathrm{vv}}+2 \times \mathrm{G} \times \mathrm{I}_{\mathrm{vh}}\right)
\end{aligned}
$$

where, $G$ is the instrumental correction factor for the fluorometer and it is defined by

$$
\mathrm{G}=\mathrm{I}_{\mathrm{hv}} / \mathrm{I}_{\mathrm{hh}}
$$

$I_{v v}, I_{v h}, I_{h v}$ and $I_{h h}$ represent the fluorescence signal for excitation and emission with the polarizers set at $\left(0^{\circ}\right.$, $\left.0^{\circ}\right),\left(0^{\circ}, 90^{\circ}\right),\left(90^{\circ}, 0^{\circ}\right)$ and $\left(90^{\circ}, 90^{\circ}\right)$ respectively.

The interaction of $\mathrm{SSB}_{\mathrm{BA}}$ with the labeled oligonucleotide can be represented as follows:

$$
\mathrm{SSB}_{\mathrm{BA}}[\mathrm{P}]+\operatorname{ssDNA}[\mathrm{R}] \leftrightarrows \mathrm{SSB}_{\mathrm{BA}} \bullet \mathrm{ssDNA}[\mathrm{RP}]
$$

Where, $\mathrm{R}$ is the ligand i.e., labeled oligonucleotides and $\mathrm{P}$ is $\mathrm{SSB}_{\mathrm{BA}}$.
At equilibrium, $\mathrm{K}_{\mathrm{A}}$, the equilibrium association constant can be given as

$$
\begin{aligned}
& \mathrm{K}_{\mathrm{A}}=[\mathrm{RP}] /[\mathrm{R}][\mathrm{P}] \\
& \mathrm{K}_{\mathrm{A}}[\mathrm{R}][\mathrm{P}]=[\mathrm{RP}]
\end{aligned}
$$

Fraction of the binding sites occupied, $f$, can be represented as

$$
\begin{aligned}
f= & {[\text { occupied binding sites }] } \\
& /[\text { total binding sites }] \\
= & {[\mathrm{RP}] /([\mathrm{R}]+[\mathrm{RP}]) }
\end{aligned}
$$

Substituting for $[\mathrm{RP}]$ and rearranging the equation we get

$$
\begin{aligned}
& f=\mathrm{K}_{\mathrm{A}} \bullet \mathrm{P} /\left(1+\mathrm{K}_{\mathrm{A}} \bullet \mathrm{P}\right) \\
& f=[\mathrm{P}] /\left([\mathrm{P}]+1 / \mathrm{K}_{\mathrm{A}}\right)
\end{aligned}
$$

Similarly, equilibrium dissociation constant $K_{D}$ $\left(K_{\mathrm{D}}=1 / \mathrm{K}_{\mathrm{A}}\right)$ can be expressed as

$$
\begin{aligned}
& f=[\mathrm{P}] /\left([\mathrm{P}]+\mathrm{K}_{\mathrm{D}}\right) \\
& \text { At } \mathrm{f}=0.5, \quad \mathrm{~K}_{\mathrm{D}}=[\mathrm{P}]
\end{aligned}
$$

Thus, $K_{D}$ can be further defined as the protein concentration at which half of the sites are occupied when ligand concentration is constant, as in the present case. Non-linear regression analysis of the anisotropy plot (anisotropy vs. $\log \left[\mathrm{SSB}_{\mathrm{BA}}\right]$ ) was carried out using Prism 6.1 software (GraphPad Software Inc., San Diego, CA) and the concentration of $\mathrm{SSB}_{\mathrm{BA}}$ required to bind $50 \%$ of oligonucleotides was computed using the following equation:-

$$
\mathrm{Y}=\mathrm{Y}_{\mathrm{MIN}}+\left[\left(\mathrm{Y}_{\mathrm{MAX}}-\mathrm{Y}_{\mathrm{MIN}}\right) /\left(1+10^{\left((\operatorname{LogEC} 50-\mathrm{X})^{\mathrm{n} \text { app }}\right)}\right)\right]
$$

where, $\mathrm{Y}_{\mathrm{MIN}}$ and $\mathrm{Y}_{\mathrm{MAX}}$ are the anisotropy values at the bottom and top plateaus respectively. $\mathrm{X}$ represents $\log$ $\left[\mathrm{SSB}_{\mathrm{BA}}\right]$ (where $\left[\mathrm{SSB}_{\mathrm{BA}}\right]$ represents total concentration of $\mathrm{SSB}_{\mathrm{BA}}$ ) and $\mathrm{X}_{0}$ is the $\mathrm{X}$ value when the anisotropy is halfway between the top and the bottom of the plot and $\mathrm{n}_{\mathrm{app}}$ is the Hill coefficient.

\section{FRET analysis of sSDNA binding by $\mathrm{SSB}_{\mathrm{EC}}$ and $\mathrm{SSB}_{\mathrm{BA}}$}

FRET analysis was used to monitor ssDNA binding by SSB as described (22). Reaction mixtures were assembled on ice and incubated at $25^{\circ} \mathrm{C}$ for $5 \mathrm{~min}$ before FRET analysis. Reaction mixtures contained $40 \mathrm{nM}$ labeled Cy5-(dT) $)_{70^{-}}$ $\mathrm{Cy} 3$ oligonucleotide and the indicated amount of $\mathrm{SSB}_{\mathrm{EC}}$ or $\mathrm{SSB}_{\mathrm{BA}}$ in a total volume of $1 \mathrm{ml}$. $\mathrm{SSB}_{\mathrm{BA}}$ or $\mathrm{SSB}_{\mathrm{EC}}$ titrations were performed with $\mathrm{PC1}$ spectrofluorometer with the monochromator set at $515 \mathrm{~nm}$ for excitation for the Cy3 
donor and with the monochromator set at $665 \mathrm{~nm}$ emissions for the Cy5 acceptor. Slit width was $8 \mathrm{~nm}$.

\section{Abbreviations}

B. anthracis: Bacillus anthracis; ssDNA: Single stranded DNA; DTT: Dithiothreitol; SDS: Sodium dodecyl sulfate; PAGE: Polyacrylamide gel electrophoresis; rNTP: Ribonucleotide triphosphate; BSA: Bovine serum albumin; SSB: Single stranded DNA binding protein; SSB $_{B A}$ : SSB of Bacillus anthracis; DnaB $\mathrm{BA}$ : DnaB helicase of Bacillus anthracis; FRET: Fluorescence resonance energy transfer; mA: Millianisotropy; kDa: Kilo Dalton.

\section{Competing interests}

The author(s) declare that they have no competing interests.

Supported by grants from the National Institute of Allergy \& Infectious Diseases, NIH and UMDNJ Foundation.

\section{Authors' contributions}

EB-F was involved in the design of the study, experiments, and manuscript preparation. JK was involved in the design of the study and carried out purification and fluorescence experiments. SB was involved in the design of the study and overall direction of the project. All authors read and approved the final manuscript.

Supported by grants from the National Institute of Allergy \& Infectious Diseases, NIH and UMDNJ Foundation.

\section{Acknowledgements}

Authors gratefully acknowledge support of this work by grants from the National Institute of Allergy \& Infectious Diseases, NIH and UMDN. Foundation. Authors wish to thank Ms. S. Rotoli and K-Y Luu for DNA helicase assay of $\mathrm{SSB}_{\mathrm{BA}}$, Ms. J. Debski for critical review of the manuscript, Ms. Julia Crawford for F-test, Mr. Robert McBride of Educational Media, UMDNJ-SOM for illustration. We also thank the anonymous reviewers for helpful suggestions and comments.

Supported by grants from the National Institute of Allergy \& Infectious Diseases, NIH and UMDNJ Foundation.

\section{Author details}

'Department of Molecular Biology, School of Osteopathic Medicine \& Graduate School of Biomedical Sciences, University of Medicine \& Dentistry of New Jersey, Stratford, NJ 08084, USA. ${ }^{2}$ Department of Bioscience Technologies, Jefferson School of Health Professions, Thomas Jefferson University, Philadelphia, PA 19107, USA.

Received: 19 January 2012 Accepted: 21 May 2012

Published: 14 June 2012

\section{References}

1. Pestryakov PE, Lavrik Ol: Mechanisms of single-stranded DNA-binding protein functioning in cellular DNA metabolism. Biochemistry (Mosc) 2008, 73(13):1388-1404.

2. Bochkarev A, Bochkareva E: From RPA to BRCA2: lessons from single-stranded DNA binding by the OB-fold. Curr Opin Struct Biol 2004, 14(1):36-42.

3. Iftode C, Daniely Y, Borowiec JA: Replication protein A (RPA): the eukaryotic SSB. Crit Rev Biochem Mol Biol 1999, 34(3):141-180.

4. Salas M, Freire R, Soengas MS, Esteban JA, Mendez J, Bravo A, Serrano M, Blasco MA, Lazaro JM, Blanco L, et al: Protein-nucleic acid interactions in bacteriophage phi 29 DNA replication. FEMS Microbiol Rev 1995, 17(1-2):73-82.

5. Meyer RR, Laine PS: The single-stranded DNA-binding protein of Escherichia coli. Microbiol Rev 1990, 54(4):342-380.

6. Sancar A, Williams KR, Chase JW, Rupp WD: Sequences of the ssb gene and protein. Proc Natl Acad Sci USA 1981, 78(7):4274-4278.

7. Sancar A, Rupp WD: Cloning of uvrA, lexC and ssb genes of Escherichia coli. Biochem Biophys Res Commun 1979, 90(1):123-129.

8. Wold MS, Li JJ, Kelly TJ: Initiation of simian virus 40 DNA replication in vitro: large-tumor-antigen- and origin-dependent unwinding of the template. Proc Natl Acad Sci USA 1987, 84(11):3643-3647.

9. Chase JW, Williams KR: Single-stranded DNA binding proteins required for DNA replication. Annu Rev Biochem 1986, 55:103-136.

10. Zou Y, Liu Y, Wu X, Shell SM: Functions of human replication protein A (RPA): from DNA replication to DNA damage and stress responses. J Cell Physiol 2006, 208 (2):267-273.
11. Shereda RD, Kozlov AG, Lohman TM, Cox MM, Keck JL: SSB as an organizer/mobilizer of genome maintenance complexes. Crit Rev Biochem Mol Biol 2008, 43(5):289-318.

12. LeBowitz $\mathrm{H}$, McMacken $\mathrm{R}$ : The Escherichia coli dnaB replication protein is a DNA helicase. J Biol Chem 1986, 261(10):4738-4748.

13. Biswas EE, Chen PH, Biswas SB: Modulation of enzymatic activities of Escherichia coli DnaB helicase by single-stranded DNA-binding proteins. Nucleic Acids Res 2002, 30(13):2809-2816.

14. Stayton MM, Bertsch L, Biswas S, Burgers P, Dixon N, Flynn JE Jr, Fuller R, Kaguni J, Kobori J, Kodaira M, et al: Enzymatic recognition of DNA replication origins. Cold Spring Harb Symp Quant Biol 1983, 47 Pt 2:693-700.

15. Stayton MM, Kornberg A: Complexes of Escherichia coli primase with the replication origin of G4 phage DNA. J Biol Chem 1983, 258(21):13205-13212.

16. Learn BA, Um SJ, Huang L, McMacken R: Cryptic single-stranded-DNA binding activities of the phage lambda $P$ and Escherichia coli DnaC replication initiation proteins facilitate the transfer of E. coli DnaB helicase onto DNA. Proc Natl Acad Sci USA 1997, 94(4):1154-1159.

17. Biswas $\mathrm{SB}$, Biswas $\mathrm{EE}$ : Regulation of dnaB function in DNA replication in Escherichia coli by dnaC and lambda P gene products. J Biol Chem 1987, 262(16):7831-7838.

18. Kreji L, Sung P: RPA not that different from SSB. Structure 2002, 10(5):601-602

19. Haseltine CA, Kowalczykowski SC: A distinctive single-strand DNAbinding protein from the Archaeon Sulfolobus solfataricus. $\mathrm{Mol}$ Microbiol 2002, 43(6):1505-1515.

20. Robbins JB, Murphy MC, White BA, Mackie RI, Ha T, Cann IK: Functiona analysis of multiple single-stranded DNA-binding proteins from Methanosarcina acetivorans and their effects on DNA synthesis by DNA polymerase BI. J Biol Chem 2004, 279(8):6315-6326.

21. Wadsworth RI, White MF: Identification and properties of the crenarchaeal single-stranded DNA binding protein from Sulfolobus solfataricus. Nucleic Acids Res 2001, 29(4):914-920.

22. Pant K, Karpel RL, Rouzina I, Williams MC: Salt dependent binding of T4 gene 32 protein to single and double-stranded DNA: single molecule force spectroscopy measurements. J Mol Biol 2005, 349(2):317-330.

23. Nakai H, Richardson CC: The effect of the $\mathrm{T7}$ and Escherichia col DNA-binding proteins at the replication fork of bacteriophage T7. J Biol Chem 1988, 263(20):9831-9839.

24. Ferrari ME, Fang J, Lohman TM: A mutation in E. coli SSB protein (W54S) alters intra-tetramer negative cooperativity and inter-tetramer positive cooperativity for single-stranded DNA binding. Biophys Chem 1997, 64(1-3):235-251.

25. Overman $L B$, Lohman TM: Linkage of $p H$, anion and cation effects in proteinnucleic acid equilibria. Escherichia coli SSB protein-single stranded nucleic acid interactions. J Mol Biol 1994, 236(1):165-178.

26. Roy R, Kozlov AG, Lohman TM, Ha T: Dynamic Structural Rearrangements Between DNA Binding Modes of E. coli SSB Protein. J Mol Biol 2007, 369(5):1244-1257.

27. Griffith JD, Harris LD, Register J 3rd: Visualization of SSB-ssDNA complexes active in the assembly of stable RecA-DNA filaments. Cold Spring Harb Symp Quant Biol 1984, 49:553-559.

28. Chrysogelos S, Griffith J: Escherichia coli single-strand binding protein organizes single-stranded DNA in nucleosome-like units. Proc Natl Acad Sci USA 1982, 79(19):5803-5807.

29. Bendtsen JD, Nilsson AS, Lehnherr H: Phylogenetic and functional analysis of the bacteriophage P1 single-stranded DNA-binding protein. J Virol 2002, 76(19):9695-9701.

30. Moreira D: Multiple independent horizontal transfers of informational genes from bacteria to plasmids and phages: implications for the origin of bacterial replication machinery. Mol Microbiol 2000, 35(1):1-5.

31. Lindner C, Nijland R, van Hartskamp M, Bron S, Hamoen LW, Kuipers OP: Differential expression of two paralogous genes of Bacillus subtilis encoding single-stranded DNA binding protein. J Bacterio/ 2004, 186 (4):1097-1105.

32. Grove DE, Willcox S, Griffith JD, Bryant FR: Differential single-stranded DNA binding properties of the paralogous SsbA and SsbB proteins from Streptococcus pneumoniae. J Biol Chem 2005, 280(12):11067-11073.

33. Read TD, Peterson SN, Tourasse N, Baillie LW, Paulsen IT, Nelson KE, Tettelin $H$, Fouts DE, Eisen JA, Gill SR, et al: The genome sequence of Bacillus anthracis Ames and comparison to closely related bacteria. Nature 2003, 423(6935):81-86 
34. Takami H, Nakasone K, Takaki Y, Maeno G, Sasaki R, Masui N, Fuji F, Hirama C, Nakamura Y, Ogasawara N, et al: Complete genome sequence of the alkaliphilic bacterium Bacillus halodurans and genomic sequence comparison with Bacillus subtilis. Nucleic Acids Res 2000, 28(21):4317-4331.

35. Genschel J, Curth U, Urbanke C: Interaction of E. coli single-stranded DNA binding protein (SSB) with exonuclease I. The carboxy-terminus of SSB is the recognition site for the nuclease. Biol Chem 2000, 381(3):183-192.

36. Curth U, Genschel J, Urbanke C, Greipel J: In vitro and in vivo function of the Cterminus of Escherichia coli single-stranded DNA binding protein. Nucleic Acids Res 1996, 24(14):2706-2711.

37. Matsumoto T, Morimoto Y, Shibata N, Kinebuchi T, Shimamoto N, Tsukihara T, Yasuoka N: Roles of functional loops and the C-terminal segment of a singlestranded DNA binding protein elucidated by X-Ray structure analysis. J Biochem 2000, 127(2):329-335.

38. Murzin AG: $\mathrm{OB}$ (oligonucleotide/oligosaccharide binding)-fold: common structural and functional solution for non-homologous sequences. EMBO J 1993, 12(3):861-867.

39. Raghunathan S, Ricard CS, Lohman TM, Waksman G: Crystal structure of the homo-tetrameric DNA binding domain of Escherichia coli single-stranded DNA-binding protein determined by multiwavelength $x$-ray diffraction on the selenomethionyl protein at 2.9-A resolution. Proc Natl Acad Sci USA 1997, 94(13):6652-6657.

40. Khopde S, Biswas EE, Biswas SB: Affinity and sequence specificity of DNA binding and site selection for primer synthesis by Escherichia coli primase. Biochemistry 2002, 41(50):14820-14830

41. Datta K, LiCata VJ: Salt dependence of DNA binding by Thermus aquaticus and Escherichia coli DNA polymerases. J Biol Chem 2003, 278(8):5694-5701.

42. Raghunathan S, Kozlov AG, Lohman TM, Waksman G: Structure of the DNA binding domain of E. coli SSB bound to ssDNA. Nat Struct Biol 2000, 7(8):648-652

43. Bordoli L, Kiefer F, Arnold K, Benkert P, Battey J, Schwede T: Protein structure homology modeling using SWISS-MODEL workspace. Nat Protoc 2009, 4(1):1-13.

44. Kiefer F, Arnold K, Kunzli M, Bordoli L, Schwede T: The SWISS-MODEL Repository and associated resources. Nucleic Acids Res 2009, 37(Database issue):D387-D392.

45. Williams KR, Murphy JB, Chase JW: Characterization of the structural and functional defect in the Escherichia coli single-stranded DNA binding protein encoded by the ssb-1 mutant gene. Expression of the ssb-1 gene under lambda pL regulation. J Biol Chem 1984, 259(19):11804-11811.

46. Bemstein DA, Eggington JM, Killoran MP, Misic AM, Cox MM, Keck JL: Crystal structure of the Deinococcus radiodurans single-stranded DNA-binding protein suggests a mechanism for coping with DNA damage. Proc Natl Acad Sci USA 2004, 101(23):8575-8580

47. Chan KW, Lee YJ, Wang CH, Huang H, Sun YJ: Single-stranded DNA-binding protein complex from Helicobacter pylori suggests an ssDNAbinding surface. J Mol Biol 2009, 388(3):508-519.

48. Lohman TM, Ferrari ME: Escherichia coli single-stranded DNA-binding protein: multiple DNA-binding modes and cooperativities. Annu Rev Biochem 1994, 63:527-570.

49. Kornberg A, Baker TA: DNA Replication. New York, NY: Freeman; 1992

50. Meyer RR, Glassberg J, Scott JV, Kornberg A: A temperature-sensitive single-stranded DNA-binding protein from Escherichia coli. J Biol Chem 1980, 255(7):2897-2901.

51. Aiello D, Barnes MH, Biswas EE, Biswas SB, Gu S, Williams JD, Bowlin TL, Moir DT: Discovery, characterization and comparison of inhibitors of Bacillus anthracis and Staphylococcus aureus replicative DNA helicases. Bioorg Med Chem 2009, 17:4466-4476.

52. Gryczynski I, Gryczynski Z, Lakowiz JR: Fluorescence anisotropy controlled by light quenching. Photochem Photobiol 1998, 67(6):641-646.

53. Lakowicz JR: Principles of Fluorescence Spectroscopy, Volume 3. New York: Springer Sciences + Business Media, LLC; 2006.

\section{doi:10.1186/1471-2091-13-10}

Cite this article as: Biswas-Fiss et al:: Thermodynamic analysis of DNA

binding by a Bacillus single stranded DNA binding protein. BMC

Biochemistry 2012 13:10.

\section{Submit your next manuscript to BioMed Central and take full advantage of:}

- Convenient online submission

- Thorough peer review

- No space constraints or color figure charges

- Immediate publication on acceptance

- Inclusion in PubMed, CAS, Scopus and Google Scholar

- Research which is freely available for redistribution 